Yeshiva University, Cardozo School of Law

LARC @ Cardozo Law

2010

\title{
The Role of Valuation in Federal Bankruptcy Exemption Process: The Supreme Court Reads Schedule C
}

David G. Carlson

Benjamin N. Cardozo School of Law, dcarlson@yu.edu

Follow this and additional works at: https://larc.cardozo.yu.edu/faculty-articles

Part of the Law Commons

\section{Recommended Citation}

David G. Carlson, The Role of Valuation in Federal Bankruptcy Exemption Process: The Supreme Court Reads Schedule C, 18 American Bankruptcy Institute Law Review 461 (2010).

Available at: https://larc.cardozo.yu.edu/faculty-articles/244 accepted for inclusion in Articles by an authorized administrator of LARC @ Cardozo Law. For more information, please contact larc@yu.edu. 


\title{
THE ROLE OF VALUATION IN FEDERAL BANKRUPTCY EXEMPTION PROCESS: THE SUPREME COURT READS SCHEDULE C
}

\author{
DAVID GRAY CARLSON*
}

INTRODUCTION

Under the Federal Rules of Bankruptcy Procedure (the "Bankruptcy Rules"), a trustee or creditor has 30 days after the conclusion of the first scheduled creditors' meetings to object to the debtor's exemption of a thing from the bankruptcy estate (the "30-day deadline"). ${ }^{1}$ The impact of this deadline has now been addressed twice by the United States Supreme Court.

In Taylor v. Freeland \& Kronz, a debtor claimed that a civil rights lawsuit was exempt. ${ }^{2}$ The trustee, Robert J. Taylor, doubted its value and thought it unworth the trouble to challenge the exemption. ${ }^{3}$ Later, following the debtor's win in the Pennsylvania Supreme Court, ${ }^{4}$ a big settlement came in. Taylor brought an avoidance action against the debtor and her attorneys to recover the proceeds. ${ }^{5}$ The

\footnotetext{
* Professor of Law, Benjamin N. Cardozo School of Law.

'FED. R. BANKR. P. 4003(b)(1) (2006) (providing "a party in interest may file an objection to the list of property claimed as exempt within 30 days after the conclusion of the meeting of creditors held under $\S$ 341 (a) is concluded or within 30 days after any amendment to the list or supplemental schedules is filed" unless court "extend[s] the time for filing objections"); Schwab v. Reilly, 130 S. Ct. 2652, 2658 (2010) ("Subject to exceptions not relevant here, the Foderal Rules of Bankruptcy Procedure require interested parties to object to a debtor's claimed exemptions within 30 days after the conclusion of the creditors' meeting held pursuant to Rule 2003(a). If an interested party fails to object within the time allowed, a claimed exemption will exclude the subject property from the estate even if the exemption's value exceeds what the Code permits." (internal citations omitted)).

${ }^{2}$ Taylor v. Freeland \& Kronz, 503 U.S. 638, 640 (1992) (noting debtor exempted proceeds relating to pending lawsuit from its schedule of assets).

${ }^{3}$ See id. at 641 ("Taylor decided not to object to the claimed exemption. The record reveals that Taylor doubted that the lawsuit had any value.").

${ }^{4}$ Winn v. Trans World Airlines, Inc., 462 A.2d 301, 305-06 (Pa. Commw. Ct. 1983) (affirming Human Relations Commission decision finding TWA discriminated against black female employee by denying her several promotions despite her qualifications), appeal dismissed, 515 A.2d 303 (1986).

${ }^{5}$ Taylor v. Freeland \& Kronz (In re Davis), 105 B.R. 288, 290 (Bankr. W.D. Pa. 1989), aff'd, 118 B.R. 272, 273, rev'd, 938 F.2d 420, 426 (3d. Cir. 1991), affd, 503 U.S. 638, 642 (1992). The trustee proceeded under Bankruptcy Code section 549(a) and section 550(a). 11 U.S.C. $\S 549$ (a) (2006) (allowing trustee to avoid certain transfers of estate property); id. $\S 550$ (a) (authorizing trustee to recover from transferee or any immediate of transferee). A section 549(a) avoidance assumes that someone had a power under state or federal law to convey an interest free and clear of the bankruptcy estate. See David Gray Carlson, Bankruptcy's Acephalous Moment: Postpetition Transfers Under the Bankruptcy Code, 21 EMORY BANKR. DEV. J. 113, 117 (2004) ("Section 549(a) avoidance becomes relevant if and only if D or some other party has an identifiable power to dispose of the bankruptcy estate, free and clear of the trustee's interest. "). Hence, this conveyance must be "avoided." If, however, the conveyance did not have the effect of defeating the trustee's property rights, then avoidance under section 549(a) is inappropriate. Id. at 118 (arguing Olsen $v$. Zerbetz, 36 F.3d 71 (9th Cir. 1994), inappropriately considered section 549(a) because debtor's conveyance of bankruptcy estate property had no possible effect on trustee's rights since debtor had no power over
} 
debtor and her lawyers responded that the civil rights lawsuit had been entirely expelled from the bankruptcy estate through exemption, that the 30-day deadline for objecting to the discharge had passed, and that this statute of limitations prohibited the trustee's avoidance action. ${ }^{6}$

The lower courts sided with the trustee, ${ }^{7}$ but the United States Supreme Court ruled that the trustee had a duty to object to the exemption. ${ }^{8}$ Not having done so, lapse of the 30-day period negated the trustee's avoidance action. ${ }^{9}$ "Deadlines may lead to unwelcome results, but they prompt parties to act and they produce finality," the Court opined. ${ }^{10}$ So the debtor got away with an asset to which her creditors were largely (but not entirely) entitled. ${ }^{11}$ Taylor is taken to mean that, if the debtor lists a blatantly non-exempt thing as exempt, and if the 30-day statute of limitations passes, the non-exempt thing is to be treated as if it were exempt. ${ }^{12}$

In the recent case of Schwab v. Reilly, the Supreme Court reached what seems at first glance to be an opposite result. ${ }^{13}$ In Schwab, a debtor was entitled to a "wildcard" exemption of $\$ 10,225$ (as was the debtor in Taylor). ${ }^{14}$ Under this provision, the debtor could exempt anything at all, so long as it was worth less than $\$ 10,225 .^{15}$ She was also entitled to exempt tools of the trade to the limit of $\$ 1,850 .^{16}$

property). Rather, the trustee should bring a turnover proceeding under Bankruptcy Code section 542(a), or, if money has been converted to their own use by the defendants, the trustee should have proceeded to collect the tort debt under section 542(b). See generally Carlson, supra (suggesting section 542(a)-(b) gives trustee power to demand payment of debt or value transferred from estate after bankruptcy commencement without avoidance action). The fact that Taylor chose to proceed by avoidance constitutes a confession that the debtor did successfolly exempt the entire lawsuit from the bankruptcy estate, such that it had to be brought back in. The better view is that the lawsuit never left the bankruptcy estate because the debtor, at most, exempted a monetarily limited portion of the lawsuit.

${ }^{6}$ In re Davis, 105 B.R. at 290.

${ }^{7} \mathrm{Id}$. at 288.

${ }^{8}$ See Taylor, 503 U.S. at 643-44 ("Taylor cannot contest the exemption at this time . . . If Taylor did not know the value of the potential proceeds of the lawsuit, he could have sought a hearing on the issue, see Rule 4003(c), or he could have asked the Bankruptcy Court for an extension of time to object, see Rule 4003(b). Having done neither, Taylor cannot now seek to deprive Davis and respondents of the exemption.").

${ }^{9}$ Id. at 642 (1992) (holding trustee may not contest validity of claimed exemption once 30 -day period has expired).

${ }^{10} I d$. at 644.

"See id. at 642 ("[D]ebtor did not have [the] right to exempt more than small portion of proceeds either under state law or under the federal exemptions specified in $\S 522(\mathrm{~d}) ")$. The debtor was entitled to the "wildcard" monetarily limited exemption in section 522(d). See infra text accompanying notes 14-15.

${ }^{12}$ See Pleasant v. TLC Liquidation Trust (In re Tender Loving Care Health Servs., Inc.), 562 F.3d 158, 163 n.6 (2d Cir. 2009) (citing Taylor, 503 U.S. at 639 (1992)) (holding that "banknuptcy trustee could not contest the validity of an exemption after the 30-day period . . . had run, despite the fact that the debtor had no colorable basis for claiming the exemption"); Ladd v. Ries (In re Ladd), 450 F.3d 751, $753 \mathrm{n} .1$ (8th Cir. 2006) ("If the Trustee does not timely object to a claim of exemption, the property will be deemed exempt, even if there is no basis for the exemption. "); In re Schoonover, 331 F.3d 575, 578 (7th Cir. 2003) ("Once the period expires, creditors are out of luck even if the claim of exemption is specious."):

${ }^{13}$ See Schwab v. Reilly, 130 S. Ct. 2652, 2669 (2010) (holding trustee was not required to object to claimed exemption).

${ }^{14} I d$. at 2657.

${ }^{15}$ Id. at 2671 n.2 ("The 'wildcard' exemption permits a debtor to shield her 'aggregate interest in any 
These she combined to create a total exemption of $\$ 12,075 .{ }^{17}$ Under this combined exemption, she claimed restaurant equipment said to be worth $\$ 10,718 .{ }^{18}$ The trustee, William G. Schwab, subjected the equipment to a valuation, which showed a value in excess of $\$ 10,225 .{ }^{19}$ Nevertheless, he let the 30 -day deadline pass. ${ }^{20}$ Later, Schwab sought to liquidate the equipment to obtain the surplus to which the general creditors were entitled. ${ }^{21}$ This time, the Supreme Court held that the deadline was not an impediment and the trustee could indeed hold an auction. ${ }^{22}$ The equipment could be expelled from the bankruptcy estate-but only insofar as the quantitative limit of $\$ 12,075$ was not exceeded. ${ }^{23}$ The surplus beyond that limit would remain inside the bankruptcy estate. ${ }^{24}$ According to the majority in Schwab, Taylor and Schwab are distinguishable and therefore harmonious holdings. ${ }^{25}$

Any bankruptcy lawyer reading $S c h w a b$ will find the opinion obtuse and difficult. It seems to be a squabble between the majority and the minority on how to read Schedule C. Schedule $C$ is the official form wherein a debtor claims exemptions pursuant to Bankuptcy Code section $522(l) .{ }^{26} \mathrm{It}$ is safe to say that never has the Supreme Court endowed an official judicial form with such extraordinary attention. But, underneath the exceedingly fine points about details of the forms, Schwab stands for an entire re-theorization of the Bankruptcy Code's exemption procedures. In this new vision, judicial valuations play no part. And because this is so, the 30-day deadline for objecting to exemptions will rarely have any bite.

In this article, I compare Taylor and Schwab and conclude that these cases are not reconcilable. The lower courts in Schwab were well-justified in ruling for the debtor on the basis of Taylor. They could not be faulted for failing to anticipate the Supreme Court's overnuling of its own precedent. In fact, the Schwab Court should

property' she chooses, up to the stated dollar limit.").

${ }_{16}^{16}$. (authorizing $\$ 1,850$ as maximum trade-tools exemption pursuant to 11 U.S.C. $\$ 552(\mathrm{~d})(6)$ (2006)).

${ }^{17} \mathrm{Id}$. at 2671.

${ }^{18}$ Id. at 2657-58.

${ }^{19} \mathrm{Id}$. at 2658 .

${ }^{20} \mathrm{Id}$. at 2658 \& n.2 (acknowledging trustee did not comply with thirty-day exemption objection period under Rule 4003(b), after which time subject property shall be excluded from bankruptcy estate, even if its value exceeds statutory cap).

${ }^{21} \mathrm{Id}$.

${ }^{22}$ Id. at $2663,2665-66$. Or, more precisely, the Schwab majority thought that passage of the 30-day period was no impediment to the auction. Id. at 2662 . It remanded the case and invited the debtor to consider perhaps other reasons why there should be no auction. Id. at 2669.

${ }_{23}$ Id. at $2668 \mathrm{n} .21$ ("Section 541 is clear that title to the equipment passed to Reilly's estate at the commencement of her case, and $\S \S 522(\mathrm{~d})(5)$ and (6) are equally clear that her reclamation right is limited to exempting an interest in the equipment, not the equipment itself.").

24 Id. at 2669 ("Schwab was not required to object to Reilly's claimed exemptions in her business equipment in order to preserve the estate's right to retain any value in the equipment beyond the value of the exempt interest.").

${ }^{25}$ See id. at 2666-67 (differentiating Taylor where debtor did not list estimated value of claimed exemption from case at hand).

${ }^{26}$ According to section $522(l)$, "[t]he debtor shall file a list of property that the debtor claims as exempt under subsection (b) of this section." 11 U.S.C. $\S 522(l)$ (2006). 
have excused the overruled Third Circuit for following Taylor, should have apologized for wrongly deciding Taylor, and should have announced that Schwab constitutes the birth of a new era in which federal exemption law is restored to a fair and rational equilibrium (after an 18 year interregnum).

Taken on its own, Schwab reaches a good and fair result, in spite of three dissenters who wished to perpetuate the bad old days of Taylor. Schwab coheres deeply with a theory of the bankuptcy estate, which I have been trying to propound for several years now. According to this theory, the trustee's personal property interest in the bankruptcy estate is the interest of a lien creditor. ${ }^{27}$ The trustee's lien always attaches to monetarily limited exemptions, even when value is estimated to be below the quantitative limit of the exemption. ${ }^{28}$ No lien, however, attaches to an "in-kind" exemption. ${ }^{29}$ The exemption of the entire "thing-in-itself" expels the item from the bankruptcy estate once and for all, once the 30 -day deadline has passed. ${ }^{30}$ The exempt thing-in-itself is a priori exempt. ${ }^{31}$ The monetarily limited exempt thing is not. ${ }^{32}$ In both Taylor and Schwab, the debtor claimed a monetarily limited exempt thing. ${ }^{33}$ In both cases, the trustee's lien survived the exemption and should have vindicated the trustee's ability to obtain the surplus beyond the monetary limit of the exemption. ${ }^{34}$ Only in Schwab was the validity of the lien recognized. ${ }^{35}$

This Article is divided into five parts. In Part I, I give some state-law background. In Part II, I set forth the federal bankruptcy regime for exemptions. In Part III, I consider whether a judicial valuation of property claimed to be exempt has any part to play in the federal exemption regime. Parts IV and V review the Taylor and Schwab opinions. They conclude that, although these cases are not reconcilable, exemption law has been restored to good sense and restful equilibrium.

\footnotetext{
${ }^{27}$ See David Gray Carlson, Bankruptcy's Organizing Principle, 26 FLA. STATE UNIV. L. REV. 549, 552 (1999) [hereinafter Carlson, Bankruptcy's Organizing Principle] (arguing strong-arm power under section 544(a) "is the bankruptcy trustee's status as hypothetical judicial lien creditor on the first day of the bankruptcy petition").

${ }^{28}$ See 11 U.S.C. $\$ 544(a)(1)$ (providing hypothetical judicial lien on all property).

${ }^{29}$ See infra note 83 .

${ }^{30}$ According to section $522(l)$, "[u]nless a party in interest objects, the property claimed as exempt on such list is exempt." 11 U.S.C. $\$ 522(l)$.

${ }^{31}$ Id.

${ }^{32}$ See Carlson, Bankruptcy's Organizing Principle, supra note 27, at 618 (arguing only debtor's equity in the exempt property up to monetary limit is what is actually exempted, and leftover equity reachable by judicial lien).

${ }^{33}$ See Schwab v. Reilly, 130 S. Ct. 2652, 2657 (2010) (discussing how debtor claimed kitchen equipment as exempt); Taylor v. Freeland \& Kronz, 503 U.S. 638, 640 (1992) (recalling how debtor claimed expected proceeds from lawsuit as monetarily limited exemption).

${ }^{34}$ See Schwab, 130 S. Ct. at 2661 (preserving lien where no exemption objection obligation); Taylor, 503 U.S. at 641-42 (deciding case based on trustee's untimely exemption objection).

${ }^{35}$ See Schwab, 130 S. Ct. at 2661 (concluding trustee had no exemption objection obligation where debtor's business property claimed as exempt).
} 


\section{THE STATE LAW BACKGROUND}

From time immemorial, legislatures have declared some property so sacred and dear to the human soul that they forbid the sheriff from levying upon it. ${ }^{36}$ In New York, for example, the family bible is one of the items off limits to debt enforcement. ${ }^{37}$ In Oklahoma, the sheriff may not levy on "[t]en hogs[] that are held primarily for personal, family or household use ....1"138

Total exemption of a thing invites over-investment in it. ${ }^{39}$ And this leads to debtor skullduggery-sometimes called "exemption planning." ${ }^{40}$ For instance, if residential real estate (i.e., the homestead) is totally exempt, as it is in some states, ${ }^{41}$ then insolvent debtors have cause to convert remaining liquid assets into the homestead, thereby shielding this wealth from the creditors. ${ }^{42}$

To prevent such debtor tactics, states often put monetary limits on exemptions. For instance, in New York, a debtor's homestead exemption is limited to $\$ 50,000 .{ }^{43}$ There are, then, two exemption regimes. One places the thing-in-itself beyond the reach of creditors. ${ }^{44}$ In this model, no judicial lien ever attaches to the thing-initself. ${ }^{45}$ No judicial lien ever smudges the pages of the family bible in New York ${ }^{46}$ or the ten hogs of Oklahoma. ${ }^{47}$

${ }^{36}$ See, e.g., OKLA. STAT. tit. 31, § 1(A)(15) (2010) (discussing specific property sheriff cannot levy upon).

${ }^{37}$ N.Y. C.P.L.R. $§ 5205(a)(2)$ (McKinney 2010) (exempting family bible from use to satisfy money judgments). But, as we shall see, plumbers can snatch the bible from the debtor, even if most other creditors can't. See infra note 46.

${ }^{38}$ OKLA. STAT. tit. $31, \S 1(\mathrm{~A})(15)$.

39 See Hon. A. Jay Cristol et al., Exemption Planning: How Far May You Go?, 48 S.C. L. REV. 715,738 (1997) ("[W]e see the mischief created by an ability to include an asset by name rather than amount. Capping total exemptions would cure this problem along with the others described above.").

${ }^{40}$ See id. at 721-22 (describing debtors who knowingly used uncapped total exemptions to retain luxurious assets).

${ }^{41}$ See, e.g., FLA. CONST. art. X, § 4(a)(1) (exempting homesteads situated on 160 contiguous acres); see also Hyman v. Plotkin (In re Hyman), 967 F.2d 1316, 1319 n.3 (9th Cir. 1992) (summarizing national homestead patterns).

${ }^{42}$ See, e.g., Ford v. Poston (In re Ford), 773 F.2d 52, 54 (4th Cir. 1985) (highlighting debtor's efforts to convert non-exempt property to homestead exempted property). A favorite tactic is to pay down the mortgage on the homestead, thereby increasing exempt debtor equity. See In re Anderson, 386 B.R. 315,317 (Bankr. D. Kan. 2008) (sustaining homestead exemption where debtor disposed of property to pay down mortgage); see also Lawrence Ponoroff, Exemption Limitations: A Tale of Two Solutions, 71 AM. BANKR. L.J. 221,229 (1997) (discussing cases where debtor liquidated nonexempt assets to purchase homestead).

${ }^{43}$ N.Y. C.P.L.R. $§ 5206$ (a) (McKinney 2010) ("[Homestead] not exceeding fifty thousand dollars . . . is exempt from application to the satisfaction of a money judgment ....").

${ }^{44}$ See N.Y. C.P.L.R. $\S 5205$ (a) ("[P]ersonal property . . . is exempt from application to the satisfaction of a money judgment ....".).

${ }^{45}$ See id.

${ }^{46}$ Actually, in New York, plumbers can get a judicial lien on the bible. See N.Y. C.P.L.R. § 5205(a)(2) (providing exemption when judgment "recovered by a domestic, laboring person or mechanic for work performed by that person in such capacity"); see also infra note 73 and accompanying text.

${ }^{47}$ OKLA. STAT. tit. $31, \S 1(\mathrm{~A})(15)$. 
The other model places a debtor's interest in a thing (as measured by a monetary value) beyond reach of the creditors, but it generally permits the judicial lien to attach $^{48}$ There it sits, like a cat in the weeds, waiting for the songbird of appreciation value to take wing. So where the equity in a New York homestead is thought to be worth less than $\$ 50,000$, a judicial lien always attaches to the house. ${ }^{49}$ If a sheriff or receiver cannot obtain a bid better than $\$ 50,000$, there can be no sale. ${ }^{50}$ But the lien never goes away (as a matter of state law). ${ }^{51}$ It lives on until the value increases sufficiently to justify the execution sale. ${ }^{52}$ Once someone is willing to bid more than $\$ 50,000$, the sale can occur. ${ }^{53}$ In such a case, the debtor obtains $\$ 50,000$ off the top. ${ }^{54}$ The sheriff takes the rest for the creditor whose judgment is being executed. ${ }^{55}$

\section{EXEMPT PROPERTY AND THE BANKRUPTCY ESTATE}

The commencement of a banknuptcy case is a transfer. By virtue of a bankruptcy petition, nearly all pre-petition property of a debtor becomes property of the bankruptcy estate, over which a trustee presides. ${ }^{56}$ But what kind of transfer is it? Does the debtor convey a fee simple absolute to the trustee? This view is occasionally asserted, ${ }^{57}$ but is hard to defend for many reasons. ${ }^{58} \mathrm{~A}$ better view is

\footnotetext{
${ }^{48}$ See N.Y. C.P.L.R. $\S 5206$ (d) ("The exemption of a homestead is not void because the value of the property exceed fifty thousand dollars but the lien of a judgment attaches to the surplus.").

${ }^{49} \mathrm{Id}$.

${ }^{50}$ See N.Y. C.P.L.R. $§ 5206$ (e) (providing sale of homestead with value exceeding fifty thousand dollars); see also David Gray Carlson, Critique of Money Judgment Part One: Liens on New York Real Property, 82 ST. JOHN'S L. REV 1291, 1385 (2008) [hereinafter Carlson, Critique of Money Judgment I] (noting under New York homestead exemption when "homestead has equity worth less than $\$ 50,000$ after all senior liens are considered, there can be no sale").

${ }^{51}$ See N.Y. C.P.L.R. $\$ 5206$ (d) (providing how judicial lien attaches to debtor's homestead where homestead's value exceeds $\$ 50,000$ ).

${ }^{52}$ See N.Y. C.P.L.R. $\$ 5206$ (e) (stating judgment creditor may commence special proceeding for sale of homestead where homestead's value exceeds $\$ 50,000$ ).

${ }^{53}$ See id.; see also Carlson, Critique of Money Judgment I, supra note 50, at 1385 (noting under New York's homestead exemption, homestead cannot be sold if equity worth less than $\$ 50,000$ after all senior liens have been considered).

${ }^{54}$ N.Y. C.P.L.R. $\$ 5206$ (e) (providing judgment debtor shall be paid $\$ 50,000$ from proceeds of judicial sale of homestead, exempt for one year after payment, as representing his or her interest in proceeds); see also Levinson v. R \& E Prop. Corp., 395 B.R. 554, 557 (E.D.N.Y. 2008) ("New York's homestead exemption is simply the right to receive the first $\$ 50,000$ in proceeds ... . The balance of proceeds, if any, is paid to the judicial lien creditor.").

${ }_{55}$ N.Y. C.P.L.R. § 5236(g) (McKinney 2010) (noting upon homestead sale, sheriff shall distribute proceeds according to judgment creditor priority); see also In re Giordano, 177 B.R. 451, 457 (Bankr. E.D.N.Y. 1995) ("New York's Homestead Exemption is simply the right to receive the first $[\$ 50,000]$ in proceeds after the satisfaction of consensual liens. The balance of the proceeds, if any, is to be paid to the judicial lien creditor. If there is not $[\$ 50,000]$ available after payment of the consensual liens, so be it. ").

${ }_{56}$ Exceptions are set forth in Bankruptcy Code section 541(b). 11 U.S.C. $\$$ 541(b) (2006). In these exceptions are retirement and ERISA plans of the debtor. Id. $\S 541(\mathrm{~b})(7)(\mathrm{B})(\mathrm{i})(\mathrm{I})$. See generally John Hennigan, Rousey and the New Retirement Funds Exemption, 13 AM. BANKR. INST. L. REV. 777 (2005).

${ }^{57}$ In re Szekely, 936 F.2d 897, 900 (7th Cir. 1991) (asserting trustee's fee simple absolute ownership of
} 
that the debtor transfers a lesser interest. Since the trustee is a creditor representative, it is natural to view the transfer as being in the nature of a lien. For example, the trustee obtains a lien on the debtor's pre-petition house ${ }^{59} \mathrm{He}$ has the right to sell it, but not the right to collect rent from the debtor prior to selling it, as lien creditors have no right of possession. ${ }^{60}$

Prior to the enactment of the Bankruptcy Code in 1978, a trustee had a judicial lien on all of the debtor's non-exempt property. ${ }^{61}$ In those days, the family bible never went into the bankniptcy estate and never suffered the attachment by the trustee's lien. The trustee simply had no right to the bible $a b$ initio. ${ }^{62}$ As to the limited real estate exemption, the trustee did have a lien as defined by state law, but it was subject to the prior charge of the debtor's monetary exemption, if that is what state law provided. ${ }^{63}$

The Bankeruptcy Code muddied considerably the crystalline vision of the Bankruptcy Act. First, it indicated that all property of the debtor went into the banlruptcy estate. ${ }^{64}$ This premise comes from section 541(a)(1) of the Bankruptcy Code, which provides:

(a) The commencement of a case ... creates an estate. Such estate is comprised of all the following property, where located and by whomever held:

(1) Except as provided in subsections (b) and (c)(2) of this section all legal or equitable interests of the debtor in property as of the commencement of the case ... ${ }^{65}$

\footnotetext{
debtor's house, but inconsistently denying that debtor is trespasser who must pay rent).

${ }^{58}$ For example, why does the debtor have the right to any surplus under 11 U.S.C. $\$ 726(a)(6)$ if the trustee is the fee simple owner? 11 U.S.C. $§ 726$ (a)(6) (granting debtor surplus property only after all other debts are paid). Only the fee simple owner has the residual right. This residual owner must be the debtor, not the trustee. See generally Carlson, Bankruptcy's Organizing Principle, supra note 27, at 565.

${ }^{59} 11$ U.S.C. $\$ 544$ (a) ("The trustee shall have ... the rights and powers of . . . (1) a creditor that ... obtains ... a judicial lien on all property on which a creditor on a simple contract could have obtained....").

${ }^{60}$ See Vladimir Elgort, Note, Do Debtors Owe Rent to their Bankruptcy Trustee for Remaining in the Home After Filing and Prior to Foreclosure, Notwithstanding a Homestead Exemption?, 23 CARDOZO L. REV. 2253, 2263, 2274 (2002) (proposing courts view trustees as mortgagees rather than fee simple holders entitled to rent collection from debtors).

${ }^{61}$ See Carlson, Bankruptcy's Organizing Principle, supra note 27, at 557 (discussing how 1898 Bankruptcy Act created "the view that the commencement of a bankruptcy proceeding constituted a transfer to the trustee in the nature of a judicial lien").

${ }^{62}$ See id. at 616-20.

${ }^{63}$ See Bankruptcy Act of 1898 , ch. 541, $\S 6,30$ Stat. 544, 548 (1898) (repealed 1978) ("This Act shall not affect the allowance to bankrupts of the exemptions which are prescribed by the State laws in force at the time of the filing of the petition in the State wherein they have had their domicile for the six months or the greater portion thereof immediately preceding the filing of the petition.").

${ }^{64}$ See 11 U.S.C. $\$ 541(a)(1)$.

${ }^{65}$ Id.
} 
Since the debtor admittedly has a property interest in the family bible, into the bankruptcy estate it goes. ${ }^{66}$ The trustee's lien attaches to the family bible after all. Equally, the limited exemptions go in entirely ${ }^{67}$ The trustee's lien therefore attached both to the surplus and also to the debtor's quantitative share of the thing.

After the creation of the estate, the Bankruptcy Code requires the debtor to fetch back the exempt property ${ }^{68}$ If the debtor doesn't petition to do so, the exempt property remains in the bankruptcy estate for the trustee to liquidate ${ }^{69}$ If the petition is made, however, and if no one objects to the exemptions within the 30-day deadline, the exempt property is expelled from the bankruptcy estate. ${ }^{70}$

Once expelled, the exempt property, in its post-bankruptcy mode, still receives federal protection. According to section 522(c):

Unless the case is dismissed, property exempted under this section is not liable during or after the case for any debt of the debtor that arose, or that is determined under section $502 \ldots$ before the commencement of the case .... ${ }^{71}$

The section goes on to make exceptions for lien creditors and for family creditors. ${ }^{72}$ Putting these exceptions aside, property successfully exempted is off limits to prepetition unsecured creditors, even where the debtor is utterly denied a discharge of debt. $^{73}$

\footnotetext{
${ }^{66}$ See Rousey v. Jacoway, 544 U.S. 320, 325 (2005) (quoting 11 U.S.C. $\$ 541(a)(1)$ ).

${ }^{67}$ In re Smith, 640 F.2d 888, 891 (7th Cir. 1981) (characterizing section 541 as "major change" from old Act because Code includes exempt property in estate).

${ }^{68}$ See Schwab v. Reilly, 130 S. Ct. 2652, 2663-64 (2010) ("[E]xemptions represent the debtor's attempt to reclaim those assets . ..."); Owen v. Owen, 500 U.S. 305, 308 (1991) ("An exemption is an interest withdrawn from the estate (and hence from the creditors) for the benefit of the debtor. ").

${ }^{69}$ See 11 U.S.C. \& 522(b)(1) ("[A]n individual debtor may exempt from property of the estate the property . ..."); id. §522(l) (requiring debtors claiming exemptions to file exemption schedule with court). Dependents are invited to step in and exempt the debtor's property. Id. ("If the debtor does not file such a list, a dependent of the debtor may file such a list, or may claim property as exempt from property of the estate on behalf of the debtor.").

${ }^{70} I d . \S 522$ (l) ("The debtor shall file a list of property that the debtor claims as exempt under subsection (b) of this section.... Unless a party in interest objects, the property claimed as exempt on such list is exempt."); FED. R. BANKR. P. 4003(b) (providing 30-day deadline).

${ }_{71}^{1}$ Id. $\$ 522(\mathrm{c})$.

${ }^{72}$ See id. $\$ 522(c)(1)-(4)$ (enumerating exceptions). In fact, the Bankruptcy Abuse Prevention and Consumer Protection Act of 2005 (BAPCPA) basically repeals state exemptions (as well as bankruptcy exemptions) for family creditors. See id. $\S 522(c)(1)$ ("[N]otwithstanding any provision of applicable nonbankruptcy law to the contrary, such property shall be liable for a debt of a kind specified in section 523(a)(5)."). See generally Alan M. Ahart, The Liability of Property Exempted in Bankruptcy for Pre-petition Domestic Support Obligations After BAPCPA: Debtors Beware, 81 AM. BANKR. L.J. 233, 233-34 (2007) (explaining how BAPCPA gives domestic support creditors superior rights against exempt property than previously provided under state exemption law).

${ }^{73}$ In re Scott, 199 B.R. 586, 594-95 (Bankr. E.D. Va. 1996) (holding debtor entitled to exemption even where plaintiff holds nondischargeable intentional tort claim). A case that sits uneasily on this divide (and one that is cited with approval by the Schwab court, Schwab v. Reilly, 130 S. Ct. 2652, 2652 n.4 (2010), is
} 
One may ask, if the discharge is denied and the case is closed, isn't it obvious that the pre-petition creditors and even the post-petition creditors must lay off the exempt property? After all, the property in question is exempt from creditors. Alas, the matter is not so simple. The Bankruptcy Code gives debtors the option to choose federal exemptions. ${ }^{74}$ When these are chosen, an exempt thing may be federally exempt but not exempt as a matter of state law. ${ }^{75}$ Section 522 (c) serves to vindicate the federally exempt item from post-bankruptcy state legal process. ${ }^{76}$

Williams v. Peyton (In re Williams), 104 F.3d 688, 689 (4th Cir. 1997), where the debtors claimed a tenancy by the entirety as exempt. Tenancies by the entireties, when they are exempt, are never exempt from the joint creditors of both spouses. In re Williams, 104 F.3d at 690. The debtors in In re Williams claimed the exemption as exempt from all creditors. Id. at 689 . In other words, they equated the tenancy with the in-kind exemption like the family bible. See id. The trustee never objected to the exemption. Id. The court held that the trustee did not need to object and that the trustee could administer the exempt property for the benefit of the joint creditors. Id. at 690 ("[B]y specifically claiming an exemption under section [522(b)(3)(B)], Williams merely claimed an exemption to which she was legally entitled - the exemption of her tenancy by the entirety from the claims of her non-joint creditors."); accord, Napomik v. Equibank \& Parkvale Sav. Assn, 679 F.2d 316, 321 (3d Cir. 1982) (stating Pennsylvania state law allows creditors to reach entirety property to satisfy debts of joint creditors). Doing so, of course, adhered to the benefit of the individual creditors of each spouse, whose pro rata claim on the rest of the bankruptcy estate would have been increased. 11 U.S.C. $\$ 726$ (c) ("Notwithstanding subsections (a) and (b) of this section, if there is property of the kind specified in section $541(\mathrm{a})(2)$ of this title . . such property or proceeds shall be segregated from other property of the estate, and such property or proceeds and other property of the estate shall be distributed ...."). It is far from clear, however, that the Bankruptcy Code permits exemption from some creditors, but not others. See Lazerow v. Lazerow (In re Lazerow), 119 B.R. 74, 77 (Bankr. D. Md. 1990) (noting joint property can be exempt from individual creditors but not joint creditors). It clearly permits total in-kind exemption of things-in-itself, when the law permits, or monetarily limited exemptions. See 11 U.S.C. $\S$ 522(b)(2)-(3) (enumerating exemptions). But it does not so clearly contemplate that the trustee can enforce the rights of some unsecured creditors against an exempt item. In re Covington, 368 B.R. at 40 (claiming family creditors could reach exempt asset, but trustee could not use this as pretext to avoid exemption). In New York, "a domestic, laboring person or mechanic" can get the family bible. N.Y. C.P.L.R. $\$ 5205(a)$. Williams stands for the proposition that the trustee might keep the bible in the bankruptcy estate so that it might be sold for the benefit of the plumber-a doubtful proposition. See Williams, 104 F.3d at 690 (finding rustee may administer such joint property for benefit of creditors). See generally David Gray Carlson, Critique of Money Judgment (Part II: Judicial Liens on New York Personal Property), 83 ST. JOHN'S L. REV. 43 (2009) [hereinafter Carlson, Critique of Money Judgment II] (exploring New York rules concerning exemptions).

The Supreme Court reads Williams as "holding that interested parties have no duty to object to a claimed exemption where the dollar amount the debtor assigns the exemption is facially within the range the Code allows for the type of property in issue." Schwab, $130 \mathrm{~S}$. Ct. at 2652 n.4. In fact, the exemption in Williams was an in-kind exemption against some (but not all) general creditors. Williams, 104 F.3d at 689-90 (claiming exemption applied to individual creditors only). It involved no dollars amounts at all. $I d$. at 689 ("[A]lthough Williams claimed an exemption for her $\$ 48,600$ interest in the real estate, she exempted that interest only from the claims of her non-joint creditors, and not from the claims of her joint creditors. ").

${ }_{75}^{74}$ See 11 U.S.C. $\S 522(\mathrm{~b}),(\mathrm{p})$.

${ }^{75}$ Id.

${ }^{76} \mathrm{Id}$. $\S 522(\mathrm{c})$. Several courts have recently declared "bankruptcy-only" exemptions unconstitutional. In re Pontius, 421 B.R. 814, 823 (Bankr. W.D. Mich. 2009) (holding Michigan's homestead exemption violated Supremacy Clause); In re Regevig, 394 B.R. 498, 500 (Bankr. D. Ariz. 2008) (observing banknuptcy exemption-defining ability rests solely with Congress); see also In re Applebaum, 422 B.R. 684, 697 (B.A.P. 9th Cir. 2009) (Markel, J., dissenting) (concluding Congress did not authorize states to enact bankruptcy-only exemptions). It should be remembered that bankruptcy-only exemptions become (in large part) effective 
Congress has also authorized state legislatures to prohibit their citizens from choosing the federal exemption. This is the so-called "opt-out" provision of the Bankruptcy Code. ${ }^{77}$ So far, 33 of the 50 states have "opted out." ${ }^{178}$ Only in 16 states (plus two territories and the District of Columbia) may debtors choose federal exemptions. ${ }^{79}$ One of these states is Pennsylvania,${ }^{80}$ in which both the Taylor and the $S c h w a b$ cases originated.

Section 522(c) protects federally exempt items, but it also serves to protect debtors who illegally list non-exempt assets on Schedule C (where the 30-day limitation period passes without the trustee's protest). Taylor is supposed to be an example of this, ${ }^{81}$ though our close inquiry of that case will reveal otherwise. Thanks to section 522(c), pre-petition creditors cannot get at non-exempt assets, if they are claimed to be exempt and the 30-day period for objection lapses. ${ }^{82}$

To recapitulate, in spite of the innovations of the Bankruptcy Code, it is clear that when the debtor retrieves from the bankruptcy estate an in-kind exemption such as the family bible, the bible emerges entirely free from the trustee's judicial lien. ${ }^{83}$ But not so the house, if the exemption is monetarily limited. ${ }^{84}$ The trustee's lien attaches to the surplus in the house.

For this reason, the trustee can sell the house to obtain non-exempt debtor equity. ${ }^{86}$ But, pursuant to state law, this judicial foreclosure is subject to the debtor's

under state law thanks to section 522(c). See 11 U.S.C. $\$ 522(\mathrm{c})$ (disabling creditors from debt collection on exempted property).

${ }^{77}$ Id. $\S 522(\mathrm{~b})(2)$ (defining state "opt-out" exemption provision); see Owen v. Owen, 500 U.S. 305, 308 (1991) (noting federal exemptions in section 522(d) apply "unless the State 'opts out' of the federal list" under section $522(\mathrm{~b})(2))$.

${ }^{78}$ See 4 COLlier on BANKRUPTCY, I 522, at 522.02 n.5 (Alan N. Resnick \& Henry J. Sommer eds., 16th ed. 2009).

${ }^{79}$ See Ahart, supra note 72 , at 238.

${ }^{80}$ See id.

${ }^{81}$ See Taylor v. Freeland \& Kronz, 503 U.S. 638, 643-44 (1992) (precluding trustee from recovering property improperly listed as exempt).

${ }^{82}$ See 11 U.S.C. § 522(c) (protecting exempt property from pre-petition creditors).

${ }^{83}$ See, e.g., Henry E. Hildebrand III, In re Reilly: A Tale of Two Exemptions: Supreme Court Grants Cert to Reexamine Taylor v. Freeland \& Kronz, 28 AM. BANKR. INST. J. 12, 12 (June 2009) (noting in-kind exemption exempts "entire listed property, without regard to its value or any dollar limitation under law").

${ }^{84}$ See supra text accompanying notes 48-52.

${ }^{85}$ See, e.g., N.Y. C.P.L.R. $§ 5206$ (d). I must acknowledge a most esoteric gap in the theory of the bankruptcy estate. The trustee's hypothetical judicial lien is described by section 544(a), where we leam that "the trustee shall have ... the rights and powers of ... (1) a creditor that ... obtains ... a judicial lien on all property on which a creditor on a simple contract could have obtained such a judicial lien." 11 U.S.C. $\S$ 544(a). A creditor on a simple contract claim, however, cannot obtain a judicial lien on in-kind exemptions. See Carlson, Bankruptcy's Organizing Principle, supra note 27, at 619 ("Judicial liens on exempt property are 'void' under section 522(f)(1)(A)."). Nevertheless, the exemption goes into the bankruptcy estate all the same. See id. at 617 ("Today, all exempt property enters the bankruptcy estate. The exemptions must be claimed by the debtor after the fact. Only then does the exempt property leave the estate."). While the property is there, and before the 30-day objection period to Schedule $C$ runs out, it is hard to say the trustee has a judicial lien on the basis of section 544(a)(1). See id. at 620 (explaining potentially exempt property goes into bankruptcy estate because of section 541(a)(3) rather than by trustee's hypothetical judicial lien).

${ }^{86}$ See Soost v. NAH, Inc. (In re Soost), 262 B.R. 68, 72 (B.A.P. 8th Cir. 2001) ("[W]here an asset such as a 
senior charge for the exemption amount. ${ }^{87}$ The trustee must therefore pay the exemption amount to the debtor before retaining the surplus for the general creditors. $^{88}$

Oddly, nothing in section 522 actually commands the trustee to hand over a cash equivalent to the debtor. ${ }^{89}$ So presumably the command for the trustee to do so comes from state law. That is, the trustee is a hypothetical judicial lien creditor under state law. ${ }^{90}$ When the trustee sells pursuant to section $363(\mathrm{~b})$ with court permission, state law compels the trustee to hand the cash over to the debtor. ${ }^{91}$ In New York, the cash proceeds of the debtor's exempt interest in the real estate is itself exempt for one year. ${ }^{92}$ If the money is used to buy a new homestead, the exemption continues. ${ }^{93}$ Unfortunately, state law does not always have a proceeds rule. ${ }^{94}$ Nor is there any governing theory for the federal exemptions of section 522(d), where they are permitted. ${ }^{95}$ To my knowledge, however, trustees universally assume that they have to give cash equivalents to the debtor, when they foreclose on monetarily limited exemptions. ${ }^{96}$

homestead is involved, claiming an exemption of a specific dollar value does not render the homestead immune from sale by the trustee in bankruptcy even though the trustee has not objected to the claimed exemption.").

${ }^{87}$ See Carlson, Bankruptcy's Organizing Principle, supra note 27, at 570 (explaining distribution of cash, subject to section 725 , after sale of a debtor's property, where debtor, as "an entity other than the estate," has an interest in surplus and must receive it "before final distribution . . . under section 726").

${ }^{88}$ See Schwab v. Reilly, 130 S. Ct. 2652, 2667 (2010) ("[T] he debtor will be guaranteed a payment in the dollar amount of the exemption.").

${ }^{89}$ See 11 U.S.C. $§ 522$ (d) (2006) (listing only monetary limit of exempt property).

${ }^{90} \mathrm{Id}$. $\S 544(\mathrm{a})(1)$ (giving trustee power of hypothetical judicial lien creditor).

${ }^{91}$ See, e.g., Hyman v. Plotkin (In re Hyman), 967 F.2d 1316, 1318-19 (9th Cir. 1992) (acknowledging homestead sale only permissible under California law where exemption limit was exceeded and debtor was first entitled to sale proceeds covering exemption), abrogated on other grounds, Schwab v. Reilly, $130 \mathrm{~S}$. Ct. 2652,2659 (2010).

92 See N.Y. C.P.L.R. $§ 5206(\mathrm{e})$ ("Money, ... paid to a judgment debtor, as representing his interest in the proceeds, is exempt for one year after the payment....").

${ }^{93}$ See id.

${ }^{94}$ See Carlson, Critique of Money Judgment I, supra note 50, at 1386-90 (discussing lack of proceeds rule in New York for mortgage foreclosure sales that generate surpluses).

${ }^{95}$ In re Healy, 100 B.R. 443, 445 (Bankr. W.D. Wis. 1989) (recognizing section 522(d)(1) does not exempt proceeds from sale of homestead).

${ }^{96}$ New York has a state-law precedent that actually interferes with this conclusion. See First Fed. Sav. \& Loan Ass'n v. Brown, 434 N.Y.S.2d 306, 310 (App. Div. 1980) (indicating proceeds from foreclosure sale are not exempt). In Brown, a debtor granted a mortgage to $A$ and lost a judgment to $J C$. Id. at 308 . $A$ then foreclosed and sold to $X$ for a price large enough to generate a $\$ 8,667$ surplus. Id. Before the surplus was distributed, the debtor filed for bankruptcy. Id. Since, at the time, New York provided a $\$ 10,000$ real estate exemption, the debtor claimed that the entire surplus was "real estate" and therefore awardable to the debtor. Id. at 308-09 (citing N.Y. C.P.L.R. § 5206(a)). The Brown court, however, ruled that, once the homestead was sold in foreclosure, the proceeds were personal property. Id. at 310 . As New York has no exemption for cash, the amount was awarded to $J C$. Id.

The debtor had the last laugh by amending her exemption schedule to switch from the state-law exemption to the wildcard federal exemption of Bankruptcy Code section 522(d)(5), which in those days permitted the exemption of any property worth up to $\$ 7,900$. See 11 U.S.C. $\S 522(d)(5)(2006)$. Furthermore, the debtor could use Bankruptcy Code section $522(\mathrm{f})$ to avoid the judicial lien because it impaired her 
We saw earlier that a state lien creditor may hang back and wait for appreciation value to accrue to the quantitatively limited exemption. ${ }^{97}$ For example, if the New York homestead is worth only $\$ 40,000$, the lien creditor must wait until the value increases. ${ }^{98}$ Then, years or even decades later, the lien creditor can swoop in and execute on the judgment, obtaining any amount over $\$ 50,000 .{ }^{99}$

Bankruptcy provides a tool to prevent this. Under section $522(\mathrm{f})(1)(\mathrm{A})$, a debtor may avoid a judicial lien to the extent it impairs an exemption. ${ }^{100}$ "Impairment" is carefully defined to allow the debtor any post-petition appreciation. ${ }^{101}$ Liens may partially survive avoidance under section $522(\mathrm{f})(1)(\mathrm{A}){ }^{102}$ The policy of section $522(\mathrm{f})$ is to guarantee to the debtor postpetition appreciation value. ${ }^{103}$

But what of the trustee with a judicial lien on the homestead? May a trustee close a case and wait in the weeds for decades, until appreciation value accrues and

exemption of the proceeds. See Brown v. Dellinger (In re Brown), 734 F.2d 119, 125 (2d Cir. 1983). Effective September 1, 1982, the New York legislature deprived its citizens of their right to elect federal exemptions in bankruptcy. See N.Y. DEBT. \& CRED. LAW § 284 (McKinney 2001): The debtor's amendment to her exemption schedule occurred in 1980. See Brown, 734 F.2d at 121-22. Therefore, the debtor's maneuver cannot be repeated. See Carlson, Critique of Money Judgment I, supra note 50, at 1386-88.

${ }_{97}$ See id. at 1385 (discussing inability of state lien creditor to sell property when equity is less than quantitatively limited exemption amount).

${ }^{98}$ See id. ("Where, however, the homestead has equity worth less than $\$ 50,00$ after all senior liens are considered, there can be no sale." (citing Reda v. Voges, 596 N.Y.S.2d 147 (App. Div. 1993))).

${ }_{99}$ See N.Y. C.P.L.R. $§ 5203(b)$ (McKinney 2010) (providing courts may extend lien period beyond ten years where more time is needed for real property sale). Liens might have to be renewed for this to happen, but this is easily done. See Carlson, Critique of Money Judgment I, supra note 50, at 1307-12.

${ }^{100}$ See 11 U.S.C. $\S 522(\mathrm{f})(1)(\mathrm{A})$.

101 Section 522(f)(2)(A) provides that:

[A] lien shall be considered to impair an exemption to the extent that the sum of-

(i) the lien;

(ii) all other lien on the property; and

(iii) the amount of the exemption that the debtor could claim if there were no

liens on the property;

exceeds the value that the debtor's interest in the property would have in the absence of any liens.

\section{Id. $\S 522(\mathrm{f})(2)(\mathrm{A})$.}

${ }_{102}$ See id. $\S 522(f)(1)(A)$ (providing debtor may not avoid judicial liens securing domestic support obligations).

${ }^{105}$ See In re Hanger, 217 B.R. 592, 594-96 (B.A.P. 9th Cir. 2003) (explaining 1994 amendment made section more debtor-friendly by allowing them "the full benefit of the exemption and the benefit of any postavoidance appreciation in the value of the property"). For example, suppose the debtor claims $\$ 50,000$ of a house as a monetarily limited exemption. The house is worth $\$ 250,000$. It is encumbered by a $\$ 230,000$ mortgage. Suppose further that $J C$ has a valid judicial lien for $\$ 1$ million, which has attached to the house. In bankruptcy, JCs lien impairs the debtor's exemption, according to the formula of section 522(b)(2). Under that formula, we are to calculate the sum of (i) the targeted lien ( $\$ 1$ million), (ii) all other valid liens $(\$ 230,000)$, and the amount of the exemption $(\$ 50,000)$. The required sum is $\$ 1,280,000$. From this sum we subtract the value of the house $(\$ 250,000)$. The resulting difference is $\$ 1,030,000$, which is the avoidance to which the debtor is entitled. Accordingly, we reduce the lien by $\$ 1,030,000$. Since the avoidance amount exceeds the lien, the lien is entirely avoided, and the debtor enjoys all post-bankruptcy appreciation value. 
then reopen the case to auction off the property? ${ }^{104}$ Although the trustee's lien is not subject to section 522(f) avoidance, the trustee's lien disappears under the provisions of section 554(c), which states:

Unless the court orders otherwise, any property scheduled under section $521(1)^{[105]}$ of this title not otherwise administered at the time of the closing of a case is abandoned to the debtor and administered for purposes of section 350 of this title. ${ }^{106}$

Abandonment is, curiously, not statutorily defined, but it is best understood as the trustee's release of his lien. ${ }^{107}$ So when a case is closed, the trustee's lien is released, and the trustee cannot ordinarily appear decades later to reclaim appreciation value. ${ }^{108}$ This is conditioned, however, on the property in question being scheduled by the debtor on her Schedule B, as required by section $521(\mathrm{a})(\mathrm{i})(\mathrm{B})(\mathrm{i}){ }^{109}$

We have already confessed to one embarrassment: section 522 has no express proceeds theory. We must now admit to a second embarrassment, heretofore unacknowledged. According to Bankruptcy Code section 544(a)(3), the trustee is no mere lien creditor but is a bona fide purchaser of real estate. ${ }^{110}$ Typically, state exemptions are not valid against purchasers, such as mortgagees. ${ }^{11 \mathrm{P}}$ We should certainly view the trustee as a purchaser of real estate but not a purchaser of fee simple absolute. The trustee should be viewed as a lien creditor because she is a creditor representative. ${ }^{112}$ In short, the purchase of the trustee is the purchase of a

${ }^{104}$ See 11 U.S.C. $\$ 350$ (b) (2006) (stating closed case may be reopened "to administer assets, to accord relief to the debtor, or for other cause").

${ }^{105}$ BAPCPA renumbered section 521(1) as section 521(a)(1), and failed to correct this cross-reference. Bankruptcy Abuse Prevention and Consumer Protection Act of 2005, § 106(d), 11 U.S.C. § 521(a)(1).

${ }^{106} 11$ U.S.C. $\S 554(c)$. According to Bankruptcy Code section 350(a), "After an estate is fully administered and the court has discharged the trustee, the court shall close the case." Id. $§ 350(\mathrm{a})$.

${ }^{107}$ See Carlson, Bankruptcy's Organizing Principle, supra note 27, at 613 (describing abandonment as "a renunciation of the trustee's judicial lien on assets").

${ }^{108}$ Catalano v. Comm'r, 279 F.3d 682, 686 (9th Cir. 2002) ("[A]bandonment is revocable only in very limited circumstances, such as 'where the trustee is given incomplete or false information of the asset by the debtor, thereby forcing a proper investigation of the asset."' (quoting Cusano v. Klein, 264 F.3d 936, 946 (9th Cir. 2001))). But see Polis v. Getaways Inc. (In re Polis), 217 F.3d 899, 901-04 (7th Cir. 2000) (suggesting lack of debtor disclosure before case closed may warrant its revival); Stoebner v. Wick (In re Wick), 249 B.R. 900, 914-15 (Bankr. D. Minn. 2000) (allowing trustee to reopen a case to obtain surplus value in exempt property where debtor prevaricated about property), aff'd on other grounds, 276 F.3d 412, 413 (8th Cir. 2002).

${ }^{109}$ See Vreugdenhill v. Navistar Int'l Transp. Corp., 950 F.2d 524, 526 (8th Cir. 1991) (holding property must be properly scheduled before close of case in order to be abandoned).

${ }^{110} 11$ U.S.C. $\$ 544(a)(3)(2006)$ ("The trustee shall have . . . the rights and powers of . . a bona fide purchaser of real property....").

${ }^{111}$ See, e.g., Rade v. Denver Pub. Sch. Credit Union (In re Rade), 205 F. Supp. 336, 339 (D. Colo. 1962) ("[W]here a mortgage is executed on exempt property, the prevailing view seems to consider the exemption waived by implication.").

${ }_{112}$ See Carlson, Bankruptcy's Organizing Principle, supra note 27, at 558 (discussing Congress's 1910 strong-arm power, under which trustees were apotheosized as ideal lien creditors because, "[a]s 
mortgage - a consensual lien on real estate. Debtor exemptions are no good against mortgages or other purchases. They are only good against judicial lien creditors. Hence, the implication of section 544(a)(3) is that real estate exemptions do not exist in bankruptcy.

Why did Congress enact section 544(a)(3)? In 1978, Congress thought that unrecorded liens should be void in bankruptcy. ${ }^{113}$ But unrecorded mortgages were usually perfectly good against the trustee's hypothetical judicial lien. In New York, for example, judicial liens are junior to unrecorded mortgages. ${ }^{114}$ So section 544(a)(3) was added to void the unrecorded mortgage. This was probably inadvisable and unnecessary, as voidable preference law adequately performs the same task. ${ }^{115}$

Be that as it may, an unintended side effect of section 544(a)(3) is that the exemption procedure in bankruptcy becomes impossible to explain with regard to real property. To see why, let us strip section 522(b) of irrelevant plumage and examine it on the assumption that state opt-out legislation applies:

(1) Notwithstanding section 541 of this title, an individual debtor may exempt from property of the estate the property listed in . . . paragraph (3)....

(3) Property listed in this paragraph is -

(A) . . . any property that is exempt under Federal law, other than subsection (d) of this section, or State or local law that is applicable on the date of the filing of the petition 116

So we are to look at state or local law to see what is "exempt." How does one tell from state law that property is "exempt"? Exempt from what? ${ }^{117}$ Typically, state

representative of creditors, the trustee succeeds to creditor power as well as to debtor property").

${ }^{13}$ See In re England Motor Co., 426 B.R. 178, 193 n.12 (Bankr. N.D. Miss. 2010) ("Congress added $\S$ 544(a)(3) to the Bankruptcy Code in 1978 to render unrecorded transfers of real property invalid against the trustee in bankruptcy.").

${ }^{114}$ See, e.g., Fed. Deposit Ins. Co. v. Malin, 802 F.2d 12, 24 (2d Cir. 1986) (holding unrecorded separation agreement transferring property is "ineffectual as against its subsequent lien"); United States v. Certain Lands Located in Hempstead, 41 F. Supp. 636, 637 (E.D.N.Y. 1941) (stating unrecorded title by deed executed before judgment entry takes precedence over judgment); Sullivan v. Corn Exch. Bank, 154 A.D.2d 292, 296 (App. Div. 1912) ("[A]n unrecorded conveyance has a preference over a judgment unless there is a superior equity in favor of the holder of the latter.").

115 See 1 GRANT GILMORE \& DaVID GRAY CARLSON, GILMORE AND CARLSON ON SECURED LENDING: CLAIMS IN BANKRUPTCY $\$ 1.10$, at 64 (Aspen Publishers, Inc. 2000) (stressing section 544(a)(3) simply duplicates voidable preference law, which has made unrecorded real estate conveyances into voidable preferences since 1938).

11611 U.S.C. $\$ 522(\mathrm{~b})(1),(3)(\mathrm{A})(2006)$.

117 In a provision relating to tenancy by the entireties, the Bankruptcy Code expands slightly and refers to 
law uses the term in connection with property that is placed beyond the reach of judicial process for debt enforcement. ${ }^{118}$ The problem is that state law testifies that mortgage liens cannot be affected by exemption statutes. ${ }^{119}$ And meanwhile section 544(a)(3) indicates that the trustee himself is a mortgage lender or (on the view I disfavor) a fee simple owner. ${ }^{120}$ Does that not mean that section 544(a)(3) overrides the right of any debtor to a real estate exemption?

Although the judiciary in bankruptcy cases is much taken with the "logic" that is internal to the law, logic sometimes gives out, as it does here. Through a deep and unspoken conspiracy, no trustee has ever made this claim. And undoubtedly, in enacting section 544(a)(3), Congress did not intend to deprive debtors of their real estate exemptions. Indeed, after BAPCPA, such a congressional intent is proven by various federal overrides of real estate exemptions added by BAPCPA. For example, according to new section 522(o):

For purposes of subsection (b)(3)(A), and notwithstanding subsection (a), the value of an interest in-

(1) real ... property that the debtor or a dependent of the debtor uses as a residence...

shall be reduced to the extent such value is attributable to any portion of any property that the debtor disposed of in the 10-year period ending on the date of the filing of the petition with the intent to hinder, delay, or defraud a creditor and that the debtor could not exempt, or that portion that the debtor could not exempt, under section (b), if on such a date the debtor had held the property so disposed of. ${ }^{121}$

Under this provision, the debtor's real estate exemption is reduced, under the specified conditions. ${ }^{122}$ So there must be an exemption in place that section 522(0) might reduce, in spite of the implications of section 544(a)(3). Let's just say that

\footnotetext{
"exempt from process." Id. § 522(b)(3)(B).

${ }_{118}$ See, e.g., N.Y. C.P.L.R. § 5205(a) ("The following personal property when owned by any person is exempt from the application to the satisfaction of a money judgment ....").

${ }^{119}$ See, e.g., John T. Mather Mem'l Hosp. v. Pearl, 723 F.2d 193, 193 (2d Cir. 1983) (discussing New York homestead exemption law capping property "not exceeding ten thousand dollars in value above liens and encumbrances" (citing N.Y. C.P.L.R. § 5206(a))).

${ }^{120}$ See In re Sullivan, 387 B.R. 353, 358 (B.A.P. 1st Cir. 2008) (noting trustee assumes mortgagee's position after avoiding mortgage under section 544); 5 COLLIER ON BANKRUPTCY, $\mid 544.05$, at 544-16 to 17 (Alan N. Resnick \& Henry J. Sommer eds., 16th ed. 2009) (suggesting section 544(a)(3) gives trustee all rights of bona fide purchaser which, by extension, includes legal title holder upon bankruptcy filing).

${ }_{121}^{11} 11$ U.S.C. § $522(0)$ (emphasis added).

${ }^{122} \mathrm{See}$ id. (reducing real estate exemption to extent of property of which debtor improperly disposed, or portion not exempted under section 522(b)).
} 
section 544(a)(3) erases itself from the Bankruptcy Code when it is time to read section 522 on exemptions. These two provisions cannot be read together in a holistic manner.

\section{The ROLE OF VALUATION IN EXEMPTIONS}

There is a matter we must discuss before we examine the Supreme Court's reading of Schedule C in Schwab. We must pause to consider the role of valuations in section 522. For the purposes of section 522, section 522(a)(2) provides:

"[V]alue" means fair market value as of the date of the filing of the petition or, with respect to property that becomes property of the estate after such date, as of the date such property becomes property of the estate. ${ }^{123}$

Notice that this definition of value is linked to a specific antecedent time. All other references to value in the Bankruptcy Code either refer to the present time ${ }^{124}$ or are simply unlinked to any time. ${ }^{125}$ Only section 522(a)(2) links value to a precise historic time. And herein is a major impediment to a holistic and sensible reading of section 522. The $S c h w a b$ majority implies that valuation plays no role in exemption procedure. ${ }^{126}$ Why, then, did Congress bother to define value for the purposes of section 522? Has section 522(a)(2) been read out of the Bankruptcy Code?

"Value" is a word that appears often throughout section 522. Let us work with a typical example, although many could have been chosen. Suppose a debtor is entitled to the federal exemption of section 522(d). According to the "jewelry" exemption of section 522(d)(4), the debtor may exempt

[t] $]$ he debtor's aggregate interest, not to exceed $[\$ 1,350]$ in value, in jewelry held primarily for the personal, family, or household use of the debtor or a dependent of the debtor. ${ }^{127}$

Suppose now that a debtor has a qualifying gem worth exactly $\$ 1,000$ (as of the day of the bankruptcy petition), and such a value is duly listed on the debtor's Schedule C. The exemption becomes final because the 30-day objection period has lapsed.

\footnotetext{
${ }^{123} I d . \S 522(\mathrm{a})(2)$.

124 See, e.g., id. $\S 1129$ (a)(7)(A)(ii) (valuing hypothetical chapter 7 dividend in context of plan confirmation "as of the effective date of the plan").

${ }_{125}^{125}$ See, e.g., id. $\$ 506(\mathrm{~b})$ (providing value of secured property without reference to time).

${ }^{126}$ Schwab v. Reilly 130 S. Ct. $2652,2663 \mathrm{n} .8$ (2010) ("Challenges to the valuation of [assets] . . are not covered by Rule 4003(b) .... Challenges to 'property claimed as exempt' as defined by the Code are covered by Rule 4003 (b) .... Our holding is confined to this point.").

${ }_{127}^{11}$ U.S.C. § 522(d)(4).
} 
The trustee, however, has found a buyer who will pay $\$ 1,500$ for the gem. ${ }^{128}$ May the auction proceed? This becomes the precise question in Schwab.

No less than three interpretations of section 522 are possible, given the invocation of "historic" value in section 522(a)(2).

(1) One interpretation is that the auction may proceed and the debtor is limited to $\$ 1,000$, because that was the value of the debtor's aggregate interest on the day of the bankruptcy petition. On this day, the trustee's hypothetical lien attaches to the gem. The gem has increased in value, and the trustee enjoys the appreciation value above $\$ 1,000$. On this vision, the trustee exploits the debtor's low-ball valuation on Schedule C.

One would like to say that, if the auction is appropriate, the debtor should receive $\$ 1,350$ in proceeds, not $\$ 1,000$, because her entitlement is "not to exceed $\$ 1,350 . "$ But $\$ 1,350$ refers- to the maximum the debtor can have given the valuation on auction day $(\$ 1,500)$, not on the day of the bankruptcy petition $(\$ 1,000)$. So, according to this first interpretation, valuation as declared by the debtor on Schedule $C$ is the maximum entitlement.

(2) Contrary to the above, it is possible to assert that, since on the day of the bankruptcy petition, the gem was worth $\$ 1,000$, the trustee's hypothetical lien on the gem is worth zero. Being worth zero, it does not exist. Under this interpretation, a monetarily limited exemption becomes an in-kind exemption (at least where the valuation is below the monetary limit in the relevant statute).

In other contexts, courts assume (tendentiously) that a lien worth zero is no lien at all. ${ }^{129}$ In chapter 13 cases, the debtor is not permitted to modify claims "secured only by a security interest in real property that is the debtor's principal interest. ${ }^{130}$ A junior mortgage may exist that is completely underwater. It would seem that these mortgages too cannot be modified in chapter 13. A mortgage is still a mortgage even if it is out of the money, for the moment. But a large majority of courts think that a junior home mortgage lender whose lien is completely underwater is not a secured creditor at all.

${ }^{128}$ These were the facts of Gebhart v. Gaughan (In re Gebhart), Nos. 07-16769, 07-35704, 2010 WL 3547641 , at *1-2 (9th Cir. Sept. 14, 2010), although the case involved a house that appreciated in value since the beginning of the case.

${ }_{129}$ See Lane v. W. Interstate Bancorp (In re Lane), 280 F.3d 663, 664 (6th Cir. 2002) (determining lienholder's claim depends on whether interest in collateral has economic value).

${ }_{130} 11$ U.S.C. § 1322(b)(2); see also Zimmer v. PSB Lending Corp. (In re Zimmer), 313 F.3d 1220, 1227 (9th Cir. 2002) (concluding wholly unsecured lien not protected by anti-modification provision); Lane $v$. W. Interstate Bancorp (In re Lane), 280 F.3d 663, 665 (6th Cir. 2002) (holding modification of unsecured loans permitted); Bartee v. Tara Colony Homeowners Ass'n (In re Bartee), 212 F.3d 277, 295 (5th Cir. 2000) (holding unsecured lienholder not afforded anti-modification protection); Pond v. Farm Specialist Realty (In $r e$ Pond), 252 F.3d 122, 127 (2d Cir. 2001) (finding lienholder's rights not subject to anti-modification protection); McDonald v. Master Fin., Inc. (In re McDonald), 205 F.3d 606, 615 (3d Cir. 2000) (holding antimodification clause does not apply to wholly unsecured mortgage).

${ }^{131}$ Bartee v. Tara Colony Homeowners Ass'n (In re Bartee), 212 F.3d 277, 288-89 (5th Cir. 2000) (collecting authorities supporting majority view). 
Applying this questionable premise to the trustee's hypothetical judicial lien, if the trustee has no lien (because it has no market value), then the gem is entirely out of the bankruptcy estate, and there can be no auction after the 30-day deadline has passed. In short, valuation changes the exemption from a monetarily limited exemption to an in-kind exemption.

To my eye, this is a category mistake. Property interests worth zero are still property interests. A mortgage lien worth nothing is still a power to sell the debtor's equity position, even if a buyer at the foreclosure sale would pay a nominal value. Such a buyer at state law is actually buying a possible future upside, if the purchased property increases in value. And, applying this insight to the trustee's hypothetical lien, this, too, should be viewed as encumbering a monetarily limited exemption, even when the value of the thing-in-itself is less than the statutory limit.

(3) A third interpretation - the one adopted by the $S c h w a b$ majority-holds that valuation plays no part in the exemption process. ${ }^{132}$ Where the debtor lists a monetarily limited exemption, the limited interest is indeed exempt, but the trustee's lien attaches to the exempt thing. ${ }^{133}$ On this view, the auction of our gem can go forward, and the debtor can have the statutory maximum of $\$ 1,350$. Most, but not all, appreciation value belongs to the trustee. The debtor obtains $\$ 350$ of appreciation to fill out the monetary exemption of $\$ 1,350$. The trustee obtains the surplus of $\$ 150$. But this interpretation would seem to deprive section 522(a)(2) of all bite. In such an interpretation, historic value of the gem on the day of the bankruptcy petition (or as of any time) does no work. Historic value is entirely otiose. The only work done is the dollar limit as set forth in the exemption statute itself. Under this interpretation, a court never has cause to make any valuation of the exempt thing.

This interpretive conundrum figured in Polis v. Getaways Inc. (In re Polis). ${ }^{134}$ There, the debtor listed a cause of action as exempt under Illinois's "wildcard" exemption for personal property. ${ }^{135}$ Given other claims, the debtor was entitled to a monetarily limited exemption of $\$ 900$ from this source. ${ }^{136}$ This she used to shield a lawsuit under the Truth in Lending Act. ${ }^{137}$ The value of this lawsuit was listed as "unknown." ${ }^{138}$ The bankruptcy case was closed, and the debtor became a classaction plaintiff against the offending travel agent. ${ }^{139} \mathrm{In}$ alliance with the class action

${ }^{132}$ See Schwab v. Reilly, 130 S. Ct. 2652, 2661 (2010) (observing section 522(b) does not refer to estimated market value); Gebhart, 2010 WL 3547641, at *3-4.

${ }^{133}$ See Schwab, $130 \mathrm{~S}$. Ct. at 2661-62 (exempting property up to defined dollar amount, not exempting actual item).

${ }^{134} 217$ F.3d 899 (7th Cir. 2000).

${ }^{135} \mathrm{Id}$. at 901 (citing Illinois law allowing $\$ 2,000$ personal property exemption).

${ }^{136}$ See id.

${ }^{137} \mathrm{Id}$.

${ }^{138}$ Polis v. Getaways, Inc., 242 B.R. 653, 654-55 (N.D. Ill. 1998), rev'd, 217 F.3d 899 (7th Cir. 2000).

${ }^{139}$ Polis v. Getaways, Inc., No. 98-C-1808, 1999 WL 135302, at *1 (N.D. Ill. Mar. 3, 1999), rev'd, 217 F.3d 899 (7th Cir. 2000). 
defendant, the trustee attempted to reopen the case to challenge the exemption, in order to take back the lawsuit. ${ }^{140}$ The lower courts granted the rustee relief. ${ }^{141}$

In remanding the case, Judge Richard Posner assumed that the entire lawsuit had been expelled from the bankruptcy estate if, on the day of the bankruptcy petition, the lawsuit was actually worth less than $\$ 900 .{ }^{142}$ So, Judge Posner assumed that the second interpretation described above was true. According to Judge Posner:

The judges who ruled against [the debtor] were plainly disturbed by the prospect of windfall gains to a debtor who by virtue of having exempted a legal claim from bankruptcy and thus put it beyond the reach of her creditors emerges from bankruptcy owning free and clear what turns out to be a valuable asset. But that possibility is built into the valuation scheme that the Bankruptcy Code uses to determine whether a debtor has exceeded her exemption. The Code provides that the "value" of property sought to be exempted "means fair market value" on the date the petition was filed ... On the date [the debtor] filed her petition in bankruptcy, she had not yet sued . . . but the legal claim on which the suit was based, having arisen out of a transaction . . . that had occurred before the petition was filed, was already "property" of the debtor and hence of the debtor's estate in bankruptcy....

The possibility that the debtor will obtain a windfall as a consequence of the exemptions recognized by the Bankruptcy Code arises from the fact that the date of valuation of an asset for purposes of determining whether it can be exempted is the date on which the petition for bankruptcy is filed; it is not a later date on which the asset may be more. Often a property appreciates in a wholly unexpected fashion. . . And so it is with a legal claim. It might when it first accrued have seemed so "far out" that its fair market value would be well within the limited of the exemption, and yet-such are the uncertainties of litigation-it might turned into a huge winner.

This feature of the Code's valuation should not be thought a disreputable loophole. If the assets sought to be exempted by the

\footnotetext{
${ }^{140}$ Polis, 242 B.R. at 655 . Reopening was based on the fact that the debtor had amended Schedule $C$ late in the case and did not notify the trustee before the case was closed. Id. Ordinarily, under section 554(c), this would have constituted an abandonment of the trustee's lien, but the lower courts were willing to reverse the abandonment under the circumstances. See Polis, 242 B.R. at 655.

${ }_{142}^{14}$ See id. at 656 (determining debtor's lawsuit could be exempted up to statutory maximum).

${ }^{142}$ In re Polis, 217 F.3d at 903 .
} 
debtor were not valued at a date early in the bankruptcy proceeding, neither the debtor nor the creditors would know who had the right to them. So long as the property did not appreciate beyond the limit of the exemption, the property would be the debtor's; if it did appreciate beyond that point, the appreciation would belong to the creditors, who thus might-if they still remembered their continent claims to the property-reclaim it many years after the bankruptcy proceeding had ended. ${ }^{143}$

Judge Posner's remarks therefore assume that the court must value assets as part of the exemption procedure. On remand, apparently, the trustee would have an opportunity to object that the value of the lawsuit was more than $\$ 900 .^{144}$ If so, the trustee's hypothetical lien would attach to the surplus. ${ }^{145}$ But if the lawsuit was worth less than $\$ 900$, then the lawsuit would be entirely expelled from the bankruptcy estate. ${ }^{146}$ The trustee's lien would not attach to it, and the debtor could keep all appreciation value. ${ }^{147}$

Now there is something absurd about this vision. Suppose the court decides that the value of the lawsuit on the day of the bankruptcy petition was $\$ 901$. The trustee wins all appreciation value of the lawsuit and comes up a big winner. But suppose the value is $\$ 899$. Now the lawsuit is entirely expelled from the bankruptcy estate. ${ }^{148}$ All appreciation value belongs to the debtor personally-as Judge Posner emphasized. This absurdity is an unavoidable consequence of the second interpretation.

Another oddity is that, if the debtor reports a value above the monetary limit, the debtor apparently concedes that the trustee has a hypothetical judicial lien on the exempt thing. The monetarily limited exemption is thus not converted into an inkind exemption. Only when the debtor reports a low value below the limit does the monetarily limited exemption magically transform into an in-kind exemption. Supposedly, this magic emanates from the debtor's report of value on Schedule C.

This second interpretation leads to the view that the trustee must challenge a valuation by the debtor within the 30-day deadline, in order to prevent the

\footnotetext{
${ }^{143}$ Id. at $902-03$ (emphasis added). In the italicized language, perhaps Judge Posner overlooks the ordinary effect of section 554(c). When a case is closed, the trustee abandons his lien; absent the unusual circumstance present in Polis, see supra note 140, abandonment cannot be reversed. Woods v. Kenan (In re Woods), 173 F.3d 770, 778 (10th Cir. 1999) (conditioning abandonment revocation on higher threshold imported from FED. R. CIV. P. 60(b)).

${ }_{144}^{14}$ In Polis, the 30-day objection period was tolled for the debtor's lack of disclosure. 242 B.R. at 655.

${ }^{145}$ In re Polis, 217 F.3d at 903.

${ }^{146} \mathrm{Id}$. at 904 .

${ }^{147} \mathrm{Id}$. at 903 .

${ }^{148}$ I compared this second interpretation to the underwater second mortgage in chapter 13 . The same dilemma exists. If the second mortgage is a dollar in the money, it cannot be modified. But if it is out of the money by a dollar, the mortgage lender is an unsecured creditor. See Zimmer v. PBS Lending Corp. (In re Zimmer), 313 F.3d 1220, 1226 (9th Cir. 2002).
} 
transformation of the monetarily limited exemption into an in-kind exemption. A judicial valuation as of the day of the bankuptcy petition becomes necessary to the exemption process, whenever a below-limit value is reported.

Significantly, all this stems from the odd definition of value in section 522(a)(2), which ties value to the historic moment when the bankruptcy petition was filed. That definition steered Judge Posner toward the second interpretation, which was the position of the Schwab dissent. ${ }^{149}$ But did Congress intend to signal the transformation of monetarily limited exemptions into in-kind definitions by defining "value" in such a peculiar way? This is a question that the Schwab majority implicitly answers with a "no." ${ }^{150}$

\section{TAYLOR}

The Supreme Court often finds itself explaining its past decisions, in an attempt to prevent misinterpretation by the lower courts. In this vein, the majority opinion in Schwab consists of a lengthy interpretation of the Taylor opinion. ${ }^{151}$ The Schwab majority reads Taylor to mean that, if the debtor absurdly names a thing that no one believes is exempt, and if the 30-day deadline passes, the debtor keeps the property and is protected forever by section 522(c) from any pre-petition creditor. ${ }^{152}$ But, under $S c h w a b$, the debtor who names a monetarily limited exemption does not get the entire thing. ${ }^{153}$ The trustee still has a judicial lien on the surplus of the real exemption, because the 30-day objection period has no bearing on the surplus beyond a genuine statutorily limited exemption. ${ }^{154}$ Given the Schwab reading of Taylor, does this distinction between in-kind and monetarily limited exemptions enjoy a valid statutory basis?

I have said that the definition of section $522(\mathrm{a})(2)$ is a disturbing factor in developing a coherent statutory interpretation of section 522. I will return to the implications of this provision later. But for section 522(a)(2)'s insistence on a historic value, it would certainly appear that the majority in Schwab has a quite coherent view of the exemption mechanism. The Schwab majority views the entire matter as interpreting what the debtor is claiming when she lists an asset as exempt on her Schedule C. ${ }^{155}$ The irony is that Schwab cannot be distinguished from

\footnotetext{
149 Wherein Judge Posner is cited with approval. Schwab v. Reilly, 130 S. Ct. 2652, 2675 (2010) (Ginsburg, J., dissenting) (quoting In re Polis, 217 F.3d at 903).

${ }^{150}$ See id. at 2663 n.10 (majority opinion) (viewing debtor's schedule entries as in-kind exemptions "would unnecessarily reat the exemption as violating the limits imposed by the Code").

${ }^{151}$ See id. at 2666-67.

${ }^{152}$ Id. at 2666 ("In Taylor, the question concerned a trustee's obligation to object to the debtor's entry . . . that was not plainly within the limits the Code allows.").

${ }^{153}$ See id. at 2662 (limiting exemption to interest in equipment and not equipment per se).

${ }^{154}$ See id. at 2661-63 (stating thirty day objection period does not apply when asset's market value within statutory limit, but does apply when asset's value exceeds statutory limitations).

${ }^{155}$ See Schwab v. Reilly, 130 S. Ct. 2652, 2661-62 (2010) (arguing exemption categories applicable to Reilly's case are monetarily limited exemptions rather than categorical exemptions).
} 
Taylor. They are exactly the same case. The Third Circuit was therefore justified in following Taylor when it supported the debtor's claim against Schwab. The Supreme Court was equally justified in overruling Taylor as bad law (as it is the sovereign privilege of the Supreme Court to change its mind). The Schwab majority wrongfully claims, however, that Taylor and Schwab are reconcilable. They are not. Properly, Schwab overrules Taylor, which was wrongly decided.

As the Schwab majority did, let us examine the Schedule B- $4^{156}$ in Taylor:

\section{Taylor's Schedule B-4}

\begin{tabular}{|l|l|l|l|}
\hline Type of Property & Description & $\frac{\text { Statutory }}{\text { Authority }}$ & Value \\
\hline $\begin{array}{l}\text { Proceeds from } \\
\text { Lawsuit }\end{array}$ & Winn v. TWA & $\begin{array}{l}\text { 11 U.S.C. } \\
\text { 522(b)(d) [sic] }\end{array}$ & \$ Unknown \\
$\begin{array}{l}\text { Claim for lost } \\
\text { wages }\end{array}$ & & & Unknown $^{158}$ \\
\hline
\end{tabular}

In claiming the lawsuit, the debtor in Taylor asserted that section 522(d) justifies the exemption. ${ }^{159}$ Being a Pennsylvania resident, she was entitled to choose the section 522(d) option. ${ }^{160}$

According to the Schwab majority, this entry onto Schedule B-4 was clear notice to Taylor that the debtor was planning skullduggery. ${ }^{161}$ This notice triggered the trustee's duty to object to the exemption or be forever foreclosed. ${ }^{162}$ By contrast, in Schwab, the trustee was not put on any such notice and therefore had no duty to object. ${ }^{163}$ As it were, the Taylor filing put a thumb in the eye of the trustee, yet the

${ }^{156}$ In 1984 , the time of the bankruptcy petition, this schedule was designated Schedule B-4. $I d$. at $2664 \&$ n.14 ("Indeed, it was not until 1991 that Schedule B-4 was redesignated as Schedule C and amended to require the estimate of market value on which Reilly so heavily relies . . . . The precise reason for the amendment is unclear."). The column headings have been shortened from the actual appearance in the form. AIso, over the years, the dollar amounts in the statutes have changed. At the risk of anachronism, I am pretending that Taylor is governed by the 2010 statutes and their monetary amounts.

157 This row of the form is based on Schwab, $130 \mathrm{~S}$. Ct. at 2665.

${ }^{158}$ This row, not mentioned in Schwab, is based on the verbal account in Taylor v. Freeland \& Kronz, 503 U.S. 638, 640 (1992).

159 Taylor v. Freeland \& Kronz (In re Davis), 105 B.R. 288, 293 (Bankr. W.D. Pa. 1989), affd, 118 B.R. 272, 273, rev'd, 938 F.2d 420, 426 (3d. Cir. 1991), aff'd, 503 U.S. 638, 642 (1992).

160 See In re Allan, 431 B.R. 580, 583 (Bankr. M.D. Pa. 2010) (noting because Pennsylvania is not "optout" state, residents have option to elect federal exemptions in bankruptcy proceedings).

${ }^{161}$ See Schwab v. Reilly, 130 S. Ct. 2652, 2666 n.16 (2010) (citing Barroso-Herrans v. Lugo-Mender (In re Barroso-Herrans), 524 F.3d 341, 345 (1st Cir. 2008)) (stating entries labeled "unknown" should raise red flag with creditors).

${ }^{162}$ See id. at $2662 \&$ n. 7.

${ }^{163}$ Id. at 2661-62. 
trustee did not respond. The Schwab filing, however, thrust no thumb into the eye of the trustee. Therefore, the trustee had no duty to object to the exemption.

In my view, the Supreme Court majority in Schwab is unconvincing as to what can be learned from the Taylor filing. Column 1 shows that the debtor was claiming a lawsuit. Lawsuits are mentioned in section 522(d)(11). An award under a crime victim's reparation law, for example, is included. ${ }^{164}$ Wrongful death, personal injury, and lost future wage "payments" (but not a lawsuit to compel payment) are likewise mentioned. ${ }^{165}$ These are all monetarily limited. ${ }^{166} \mathrm{I}$ assume that "payment" in section 522(d)(11) is a clumsy way of saying that the lawsuit to compel a future payment is also exempt (even though the payment has not yet been accomplished). Apart from section 522(d)(11), section 522(d)(5) allows a monetarily limited "wildcard" exemption. ${ }^{167}$ The debtor can claim any property as exempt according to the following monetary limit. ${ }^{168}$ According to the modern version of section 522(d)(5):

The debtor's aggregate interest in any property, not to exceed in value $[\$ 1,150]$ plus up to $[\$ 10,825]$ of any unused amount of the [real estate] exemption provided under paragraph (1) of this subsection. ${ }^{169}$

So, in reading the Taylor schedule, the trustee could conclude that Winn $v$. Trans World Airlines, Inc ("Winn v. TWA") ${ }^{170}$ might be in the nature of a limited personalinjury-style lawsuit under section 522(d)(11), or that this lawsuit is a wildcard claim. Nothing on this form is absolutely conclusive of the debtor's intent to claim an inappropriate exemption.

\footnotetext{
${ }^{164}$ See 11 U.S.C. $\$ 522(\mathrm{~d})(11)$ (A) (2006).

${ }^{165}$ See id. $\S 522(\mathrm{~d})(11)(\mathrm{B}),(\mathrm{D})-(\mathrm{E})$.

${ }^{166}$ The wrongful death and future wage "payments" are limited to what is reasonably necessary for the support of the debtor and her dependents. See id. $\S 522(\mathrm{~d})(11)(\mathrm{B}),(\mathrm{E})$. The personal injury "payment" may not exceed \$21,625. See id. § 522(d)(11)(D); Revision of Certain Dollar Amounts in the Bankruptcy Code Prescribed Under section 104(a) of the Code, 75 Fed. Reg. 8747, 8748 (Feb. 25, 2010) (adjusting amount to $\$ 21,625$, pursuant to section $104(\mathrm{a}))$.

${ }_{167}^{16}$ Id $\S 522(\mathrm{~d})(5)$ (exempting "debtor's aggregate interest in any property").

${ }^{168} I d$.

${ }^{169}$ Id. As the Supreme Court explains:
}

The 1994 version of 11 U.S.C. $\S 522$ (d)(5) allowed debtors to exempt an "aggregate interest in any property, not to exceed in value $\$ 800$ plus up to $\$ 7,500$ of any unused amount of the [homestead or burial plot] exemption provided under [§522(d)(1)]." In 2004 , pursuant to $\S 104(\mathrm{~b})(2)$, the Judicial Conference of the United States published notice that $\S 522(\mathrm{~d})(5)$ would impose the $\$ 975$ and $\$ 9,250$ ( $\$ 10,225$ total) limits that governed Reilly's April 2005 petition. In 2007 and 2010 the limits were again increased.

Schwab v. Reilly, 130 S. Ct. 2652, 2658 n.1 (2010) (citations omitted).

${ }^{170} 484$ A.2d 392 (Pa. 1984). 
A prudent trustee will use the occasion of the creditor's meeting to ask about the nature of Winn v. TWA. The trustee, Robert J. Taylor, did just that and found out that it was a civil rights lawsuit. ${ }^{171}$ Armed with this information, the trustee was now on notice that the debtor must be claiming the lawsuit as a wildcard exemption, or perhaps the exemption under section 522(d)(11)(E), relating to "loss of future earnings of the debtor." ${ }^{172}$ As such, a monetarily limited exemption was validly claimed. ${ }^{173}$

In the Schwab Court's revisiting of Taylor, the Court had this to say:

The interested parties in Taylor agreed that this entry rendered the debtor's claimed exemption objectionable on its face because the exemption concerned an asset (lawsuit proceeds) that the Code did not permit the debtor to exempt beyond a specific dollar amount .... In Taylor, the question concerned a trustee's obligation to object to the debtor's entry of a "value claimed exempt" that was not plainly within the limits the Code allows. ${ }^{174}$

In other words, the debtor in Taylor put her thumb in the eye of the trustee, and the trustee was obliged to avenge the insult by objecting within the 30 -day period.

The accuracy of this reading must be questioned. The lawsuit could have had a very low value, given the probability of success, and therefore could have fit within the wildcard exemption ${ }^{175}$ or perhaps the future wage exemption. If so, there was no "thumb in the eye" of Mr. Taylor. Indeed, whenever section 522(d) might be chosen in the 16 states that still allow it, the wildcard exemption alone indicates that anything claimed is rightfully exempted if the value is low enough.

In Schwab, the Court put enormous stress on the fact that the debtor in Taylor listed the value of the claimed exemptions as "unknown."

In holding [against Schwab, the trustee], the Court of Appeals focused on what it described as Taylor's "unstated premise" that "'a debtor who exempts the entire reported value of an asset is claiming the "full amount," whatever it turns out to be.'" But Taylor does not rest on this premise. It establishes and applies the straightforward proposition that an interested party must object to a

171 Taylor v. Freeland \& Kronz, 503 U.S. 638, 640 (1992) (describing discussion between trustoe and debtor counsel at initial creditors meeting).

${ }^{172}$ See id. at 642.

${ }^{173}$ Id. ("The parties agree that Davis did not have a right to exempt more than a small portion of these proceeds either under state law or under the federal exemptions specified in $\S 522$ (d)."); id. at 648 (Stevens, J., dissenting) ("[I]t is apparently undisputed that there was no legitimate basis for the claim of an exemption for the entire award.").

${ }^{174}$ Schwab, 130 S. Ct. at 2666 (citation omitted).

${ }^{175}$ As in Polis v. Getaways, Inc. (In re Polis), 217 F.3d 899, 902 (7th Cir. 2000) (using Illinois wildcard). 
claimed exemption if the amount the debtor lists as the "value claimed exempt" is not within statutory limits, a test the value (\$ unknown) in Taylor failed, and the values $(\$ 8,868$ and $\$ 1,850)$ in this case pass. ${ }^{176}$

Thus, "value unknown" in Toylor was supposed to be a red flag, warning the trustee that the debtor was up to skullduggery.

This remark does not hold up under careful scrutiny. First, let me observe that the Supreme Court's remark suffers from conflating modern Schedule $\mathrm{C}$ with 1984's Schedule B-4, set forth above. Here are the column headings for modern Schedule C:

\begin{tabular}{|c|c|c|}
\hline$\frac{\text { Description }}{\text { of Property }}$ & $\frac{\text { Specify Law }}{\text { Providing Each }}$ & $\frac{\text { Value of }}{\text { Claimed }}$ \\
\hline
\end{tabular}

$\frac{\frac{\text { Current }}{\text { Value of Property }}}{\text { Without Deduction }}$

In the above passage, the Court assumes the debtor in Taylor filled out schedule C and, in column 3, listed value as "unknown." ${ }^{178}$ Now, had the debtor in Taylor filled out modern Schedule $\mathrm{C}$ in this way, the trustee is supposed to be on notice that the debtor wishes to behave illegally. But this is not the case. Rather, the trustee is entitled to think that the debtor's lawyer was simply too lazy to look up and list the monetary exemptions set forth in section 522(d). There is no reason to think that the debtor wished to exceed the limits of the law just because those statutory limits are described as "unknown" to the debtor. ${ }^{179} \mathrm{Be}$ that as it may, the debtor in Taylor never did fill out modern Schedule C. ${ }^{180}$ She filled out a much different schedule B4 , which has no such column. In fact, on old Schedule B-4, the word "unknown" is listed in the fourth column-labeled "Value." The debtor is simply reporting that she didn't know the value of the pending civil rights suit-a statement that is undoubtedly true, given its litigation posture. This does not signal the debtor's intent to claim more than the law allows. It is quite consistent with lawful activity. As the $S c h w a b$ majority itself emphasizes, there is a "presumption that parties act

\footnotetext{
${ }^{176}$ Schwab v. Reilly, 130 S. Ct. 2652, 2666 (2010).

${ }^{177}$ Barroso-Herrans v. Lugo-Mender (In re Barroso-Herrans), 524 F.3d 341, 345 (1st Cir. 2008) ("Use of terms like ' $100 \%$ of the property's value],' 'unknown,' 'to be determined,' 'tba' and ' $\$ 1.00$ ' are red flags to trustees and creditors.").

${ }^{178}$ See Schwab, 130 S. Ct. at 2666 (citation omitted).

179 See Stoebner v. Wick (In re Wick), 276 F.3d 412, 416 (8th Cir. 2002) ("We reject Ms. Wick's contention that listing 'unknown' as the current market value of the exemptions is sufficient as a matter of law to make an asset fully exempt. Indeed, it may signal nothing more than that the asset has not been valued or that the debtor is unsure of how to come up with an accurate market value.").

${ }^{180}$ Taylor v. Freeland \& Kronz, 503 U.S. 638, 651 n.6 (1992).
} 
lawfully and with knowledge of the law." ${ }^{181}$ So, in Schwab, the Supreme Court is quite unconvincing that Taylor and Schwab are at all distinguishable.

Nevertheless, even if the Court's analysis of Taylor is not convincing, the positive law that emerges from its analysis is clear. Where, on the face of Schedule $\mathrm{C}$, the debtor clearly manifests an intent to violate the law, the trustee must object to the exemption within 30 days or be forever barred. ${ }^{182}$ But where Schedule $\mathrm{C}$ is facially lawful, the trustee sacrifices no rights by failing to object to the exemption. ${ }^{183}$ The monetarily limited exemption is partially expelled from the bankruptcy estate, but the trustee retains his lien on the surplus for the duration of the case until the case is closed. ${ }^{184}$

\section{SCHWAB}

In Taylor, as re-read by the $S c h w a b$ court, the debtor put her thumb in the eye of the trustee by claiming a blatantly illegal exemption. ${ }^{185}$ This occurred because the debtor listed as "unknown" the value of a lawsuit. ${ }^{186}$ Having failed to object, the trustee was barred from seeking any proceeds of the civil rights lawsuit. ${ }^{187}$ We have presented very severe reasons to doubt this is true, but we will accept the analysis, for the purpose of the ensuing discussion.

In Schwab, the debtor submitted the following Schedule C:

\begin{tabular}{|l|l|l|l|}
\hline $\begin{array}{l}\text { Description } \\
\text { of Property }\end{array}$ & $\begin{array}{l}\text { Specify Law } \\
\text { Providing Each } \\
\text { Exemption }\end{array}$ & $\begin{array}{l}\text { Value of Claimed } \\
\text { Exemption }\end{array}$ & $\begin{array}{l}\text { Current Market Value of } \\
\begin{array}{l}\text { Property Without } \\
\text { Deduction Exemption }\end{array}\end{array}$ \\
\hline $\begin{array}{l}\text { Listed } \\
\text { business } \\
\text { equipment }\end{array}$ & $\begin{array}{l}\text { §52(d)(6) } \\
\text { 522(d)(5) }\end{array}$ & 1,850 & 10,718 \\
\hline
\end{tabular}

${ }_{181}^{181}$ Schwab, 130 S. Ct. at 2666 (citing United States v. Budd, 144 U.S. 154, 163 (1892)).

${ }^{182}$ Id.

${ }^{183}$ Id. ("The amounts Reilly listed in the Schedule $\mathrm{C}$ column titled 'Value of Claimed Exemption' are facially within the limits the Code prescribes and raise no warning flags that warranted an objection.").

${ }_{184}^{184}$ See 11 U.S.C. $\$ 544$ (a) (2006) (granting to trustee rights of hypothetical lien creditor).

${ }^{185}$ See Schwab, 130 S. Ct. at 2665-66 (citing Taylor, 503 U.S. at 642) (explaining debtor's claim was "objectionable on its face" when form did not include monetary value).

${ }^{186}$ See id.

${ }^{187}$ See id. at 2666.

${ }^{188} \mathrm{Id}$. at 2660. 
The fourth column, confusingly put forth on Schedule $\mathrm{C}$, seems to be calling for the market value of the entire thing as to which the debtor claims a monetarily limited exemption.

As in Taylor, the trustee, William G. Schwab, executed his duty to investigate. ${ }^{189} \mathrm{He}$ had obtained a valuation of $\$ 17,200$ for the equipment. ${ }^{190}$

Let us pause and ask what would be the case if the debtor in Schwab had listed the value of the equipment as $\$ 17,200$. Schedule $\mathrm{C}$ communicates the debtor's intent to claim monetarily limited exemptions on things worth more than the limit. There would be no required "thumb in the eye" here. ${ }^{191}$ So where she lists a value less than the limit, there is even less reason to find a thumb in the trustee's eye. ${ }^{192}$ As a result, the lapse of the 30-day objection period meant only that the debtor got what she asked for-a lawful exemption limited to $\$ 11,075$ (the sum of Column 3). The trustee's lien on any surplus remained intact. Accordingly, the trustee had a power of sale that would endure so long as the case was not closed. No magic transformation of the monetarily limited exemption into an in-kind exemption occurs. ${ }^{193}$

${ }^{189} I d$ at 2658 .

$190 \mathrm{Id}$.

191 The Supreme Court understated the matter in writing: "Sections 522(d)(5) and (6) further and plainly state that claims to exempt such interests are statutorily permissible, and thus unobjectionable, if the value of the claimed interest is below a particular dollar amount. "Id. at 2662 (footnote omitted). In fact, claims under section 522(d)(5) and (6) are valid no matter what the collateral is worth (though the claim in question is monetarily limited). Id. at 2663 . Knowing this, the $S c h w a b$ majority remarked that:
Schwab was entitled to evaluate the propriety of the claimed exemptions based on three, and only three, entries on Reilly's Schedule C: the description of the business equipment in which Reilly claimed the exempt interests; the Code provisions governing the claimed exemptions; and the amounts Reilly listed in the column titled "value of claimed exemption."

Id. The omitted column 4 is irrelevant whether it states a too-high or too-low amount. The purpose of column 4, the Supreme Court opines, is to save the trustee the trouble of flipping to Schedule B to find out the value of an item listed in Schedule C. Id. at 2664.

192 The majority supported its conclusion by stating:

\begin{abstract}
Treating such claims as unobjectionable is consistent with our precedents. See, e.g., Rousey v. Jacoway, 544 U.S. 320, 325 (2005). It also accords with bankruptcy court decisions holding that where, as here, a debtor claims an exemption pursuant to provisions that (like $\S 522(\mathrm{~d})(6))$ permit the debtor to exclude from the estate only an "interest" in certain property, the "property" that becomes exempt absent objection, $\S$ $522(l)$, is only the "partial interest" claimed as exempt and not "the asset as a whole," e.g., In re Soost, 262 B.R. 68, 72 (B.A.P. 8th Cir. 2001).
\end{abstract}

Schwab, 130 S. Ct. at 2663 n.9.

${ }^{193}$ The $S c h w a b$ majority insists such a transformation does not take place. Monetarily limited exemptions "define the 'property claimed as exempt' as an 'interest' in [the debtor's] business equipment, not as the equipment per se." Id. at 2662.

We decline to construe ... exemptions in a manner that elides the distinction between 
The Schwab majority, therefore, disagreed with the unanimous opinion of the lower courts. ${ }^{194}$ None of the lower courts thought that the trustee's lien survived the 30-day statute of limitations. ${ }^{195}$ These courts considered the trustee's lien on the surplus to be canceled at the end of the 30 -day period. ${ }^{196}$ In its reading of Taylor, ${ }^{197}$ the Third Circuit cited with approva $1^{198}$ the Eleventh Circuit's conclusion in Allen $v$. Green (In re Green):

Thus, an unstated premise of [the Taylor Court] was that a debtor who exempts the entire reported value of an asset is claiming the "full amount," whatever it turns out to be. ${ }^{199}$

In short, the Third and Eleventh Circuit plausibly read Taylor to mean that, unless the debtor expressly denied seeking the whole thing, she is presumed to be

[in-kind exemptions] and provisions such as $\S 522(\mathrm{~d})(5)$ and (6), particularly based upon an entry on Schedule C-[the debtor's] estimate of her equipment's market value - to which the Code does not refer in defining the "property claimed as exempt."

Id. at 2663 (citation omitted).

Viewing the entries otherwise, i.e., as exempting the equipment in kind . . . no matter what its dollar value, would unnecessarily treat the exemption as violating the limits imposed by the Code ..., as well as ignore the distinction between those provisions and the provisions that [authorize in-kind exemptions].

Id. at 2663 n. 10.

${ }^{194}$ See id. at 2659.

${ }^{195}$ See In re Reilly, 534 F.3d 173, 174, 178, 180 (3d Cir. 2008) ("But once Rule 4003's 30-day period elapsed without Schwab filing an objection or a request for extension, the property became fully exempt from the bankruptcy estate regardless of its ultimate market value."), aff d, 403 B.R. 336 (Bankr. M.D. Pa. 2006), rev'd sub nom. Schwab v. Reilly, 130 S. Ct. 2652 (2010).

${ }^{196}$ See id. at 178.

${ }^{197}$ According to the Third Circuit, "it was important to the Taylor Court that the debtor meant to exempt the full amount of the property by listing 'unknown' as both the value of the property and the value of the exemption ...." Id. Although the Third Circuit was right that the Taylor result demanded the same result in Schwab, it is not correct that the Taylor Court made something of the word "unknown." Indeed, the Taylor court merely mentions it and makes nothing of it. See Taylor v. Freeland \& Kronz, 503 U.S. 638, 640 (1992) (using word "unknown" once to describe property's claimed value). And furthermore, on a careful reading of Taylor, the debtor said nothing at all about claiming more than the monetarily limited amount. Id. ("[P]roperty [was described by debtor] as 'proceeds from lawsuit-[Davis] v. TWA' and 'Claim for lost wages' and [debtor] listed its value as 'unknown."'). Indeed, the Taylor Court was directly aware that Taylor's claim succeeded in bringing the lawsuit at least under the wildcard exemption. See id. at 648 (Stevens, J., dissenting) ("[I]t is apparently undisputed that there was no legitimate basis for the claim of an exemption for the entire award."). Yet, nevertheless, the debtor in Taylor prevailed.

${ }^{198}$ The Third Circuit in In re Reilly praised the Eleventh Circuit's similar stance to its own on exemptions that claim the full value of an asset. 534 F.3d at 179. The Eleventh Circuit in Allen v. Green (In re Green), 31 F.3d 1098, 1101 (11th Cir. 1994), abrogated by Schwab v. Reilly, 130 S. Ct. 2652, 2663 (2010), held that an asset will become fully exempt from the banknuptcy estate when the debtor has demonstrated her intent to exempt the entire value of the asset from the estate and the trustee fails to object pursuant to Rule 4003 .

${ }^{199} 31$ F.3d at 1100 . 
overreaching and must be challenged within the 30 -day objection period. The Third Circuit was certainly correct that there is no real distinction between the Taylor schedule and the Schwab schedule. So the Third Circuit justifiably felt compelled to conclude that, per Taylor, the Schwab debtor was likewise entitled to the thingin-itself, not just the monetarily limited exemption.

The Supreme Court in Schwab made clear that the key to the case was Column $3{ }^{200}$ In Column 3, the debtor in Schwab claimed limited exemptions only. ${ }^{201}$ According to the $S c h w a b$ majority:

[A]n interested party must object to a claimed exemption if the amount the debtor lists as the "value claimed exempt" is not within statutory limits, a test the value (\$ unknown) in Taylor failed, and the values $(\$ 8,868$ and $\$ 1,850)$ in this case pass. ${ }^{202}$

Helpfully, the Supreme Court gives advice to those debtors who wish to flaunt the law by making illicit claims with regard to monetarily limited exemption. ${ }^{203}$ The key is to write "full market value" in the third column:

Where, as here, it is important to the debtor to exempt [illegally] the full market value of the asset or the asset itself, our decision will encourage the debtor to declare the value of her claimed exemption in a manner that makes the scope of the exemption clear, for example, by listing the exempt value as "full fair market value (FMV)" or "100\% of FMV." Such a declaration will encourage the trustee to object promptly to the exemption if he wishes to challenge it and preserve for the estate any value in the asset beyond relevant statutory limits. If the trustee fails to object...., the debtor will be entitled to exclude the full value of the asset. ${ }^{204}$

${ }^{200}$ See Schwab, 130 S. Ct. at 2663 ("[W] conclude that Schwab was entitled to evaluate . . the claimed exemptions based on three, and only three, entries on Reilly's Schedule C: the description of [the exemptions]; the Code provisions governing the claimed exemptions; and the amounts ... listed in [Column 3] titled 'value of claimed exemption."' (emphases added)).

${ }^{201}$ See id. at 2657-58.

${ }^{202}$ Id. at 2666; see also id. at 2660 ("Schwab and the United States as amicus curiae argue that the Code specifically defines the 'property claimed as exempt' as an interest . . . in a particular asset, not as the asset itself. Accordingly, they argue that the value of the property claimed exempt, i.e., the value of the debtor's exempt interest in the asset, should be judged on the value the debtor assigns the interest, not on the value the debtor assigns the asset.").

${ }^{203}$ See id. at 2668 (explaining how debtors can retain personal property by listing exempt items at full market value). Oddly, in Taylor, the Supreme Court threatens these same lawless debtors with civil and criminal sanctions. See Taylor v. Freeland \& Kronz, 503 U.S. 638, 644 (1992). Now it gives advice to debtors on how to scam the system. See Schwab, 130 S. Ct. at 2668.

204 Id. 
Meanwhile, the fourth column was simply the debtor's estimate of the value of the entire thing-in-itself ${ }^{205}$ in which the debtor claimed a limited interest.

The Schwab dissent, in contrast, insisted that Column 4 governs all:

The Court's account, however, shuts from sight the vital part played by the fourth entry on Schedule C - - current market value-when a capped exemption is claimed. A debtor who estimates a market value below the cap, and lists an identical amount as the value of her claimed exemption, thereby signals that her aim is to keep the listed property in her possession, outside the estate-in-bankruptcy. In contrast, a debtor who estimates a market value above the cap, and above the value of her claimed exemption, thereby recognizes that she cannot shelter the property itself and that the trustee may seek to sell it for whatever it is worth. Schedule C's final column, in other words, alerts the trustee whether the debtor is claiming a right to retain the listed property itself as her own, a right secured to her if the trustee files no timely objection. ${ }^{206}$

But on the unimportance of Column 4, the majority is clearly in the right. Where Column 3 indicates that the debtor seeks only the statutory monetarily limited exemption, nothing in Column 4 is relevant. ${ }^{207}$ If the debtor lists a high value or a low value, the key is Column 3. Similarly, if Column 3 claims all value (not just the statutory limit), ${ }^{208}$ the Column 4 listing is likewise just as irrelevant. ${ }^{209}$

${ }^{205}$ What Kant might have called "noumenal value." See generally IMMANUEL KANT, CRITIQUE OF PURE REASON 187 (J.M.D. Meiklejohn trans., Forgotten Books 2008) (1781).

${ }^{206}$ Schwab, 130 S. Ct. at 2673 (Ginsburg, J., dissenting) (footnotes omitted).

${ }^{207}$ See id. at 2663 (majority opinion) (explaining market value estimate on Schedule C serves only advisory function for trustee); see also id. at 2662 (finding section 522 describes exempted "property" as interest at specified dollar amount). Therefore, to be rejected is Barroso-Herrans v. Lugo-Mender (In re Barroso-Herrans), 524 F.3d 341, 344 (1st Cir. 2008), where the debtor implausibly listed the value of a cause of action as $\$ 4,000$. The court held that the debtor was entitled only to $\$ 4,000$. Id. at 346 . But this column 4 number should have been irrelevant. The debtor should have received the proper monetarily limited exemption that the law allowed.

${ }^{208}$ The Schwab dissent worries that this advice bids naîve consumer debtors to ignore the instruction that Column 3 gives: "Chapter 7 debtors are often unrepresented. How are they to know they must ignore Schedule C's instructions and employ the 'warning flag' described today by the Court, if they wish to trigger the trustee's obligation to object to their market valuation in a timely fashion?" Id. at 2677 (Ginsburg, J. dissenting); see also Olson v. Anderson (In re Anderson), 377 B.R. 865, 875-76 (B.A.P. 6th Cir. 2007) (suggesting Schedule $\mathrm{C}$ does not clearly state how to claim assets in full but can be claimed if amount listed indicates intent to exempt in full). But given that we are dealing with cheating debtors who wish better entitlement than the law allows, why should the forms describe how debtors might best flaunt the system? The dissent (and even the majority) shows more concern for the welfare of bad faith debtors than one usually encounters in bankruptcy appellate opinions. Compare Schwab, $130 \mathrm{~S}$. Ct. at 2668 (describing how debtors can claim assets by valuing them at "full fair market value"), and id. at 2677 (Ginsburg, J., dissenting) (arguing majority's recommendation to debtors to claim full market value is inconsistent with Schedule C's instructions), with Hyman v. Plotkin (In re Hyman), 967 F.2d 1316, 1319 (9th Cir. 1992) (finding debtors claimed only listed monetary value, not homestead itself). 
An issue that agitated the dissent was the exchange between Mr. Schwab and the debtor at the creditors' meeting in her case. According to the dissent:

Her filing left no doubt that her exemption claim encompassed her entire inventory of kitchen equipment. Schwab, in fact, was fully aware of the nature of the claim Reilly asserted. At the meeting of creditors, Reilly reiterated that she sought to keep the equipment in her possession; she would rather discontinue the bankruptcy proceeding, she made plain, than lose her equipment. ${ }^{210}$

So the trustee knew that the debtor deplored an auction before the 30-day period was up. But why should this mean that he must object to the exemption to preserve the auction? The auction was his duty and right, if he thought the sale would yield a surplus for the debtor. ${ }^{211}$ Just because the debtor has orally expressed her disappointment at the exercise of this right does not mean the right must be vindicated by some further action within the 30-day deadline. The right exists and is fully vested, regardless of the debtor's subjective opinion of it.

The majority's position is that the claimed exemption must be set forth on Schedule C. ${ }^{212}$ The debtor's orally expressed disappointment in the prospect of an auction cannot be taken as an amendment to Schedule C. ${ }^{213}$ In any case, it does not follow that the debtor should be taken as demanding that she deserved more than the law deigned to give her. Upon being informed of new facts and the consequences of those facts, she did not respond by saying, "I demand more than I am entitled to." Rather, her response was to attempt to dismiss the bankruptcy. In fact, Bankruptcy Rule 4003(b) indicates that the debtor is expected to amend

${ }^{209}$ In this respect, the dissent misreads the majority opinion: "So long as a debtor values her claimed exemption at a dollar amount below the statutory cap, the Court reasons, the claim is on-its-face permissible no matter the market value she ascribes to the asset." Schwab, $130 \mathrm{~S}$. Ct. at $2672-73$ (2010) (Ginsburg, J., dissenting). Such a view would make column 4 relevant, which the majority thinks it is not. Id. at 2663 (majority opinion).

${ }^{210}$ Id. at 2672 (Ginsburg, J., dissenting).

Schwab informed Reilly at the meeting of creditors that he planned to sell all of her business equipment. She promptly moved to dismiss her bankruptcy petition, stating that her "business equipment ... is necessary to her livelihood and art, and was a gift to her from her parents." She "d[id] not desire to continue with the bankruptcy," she added, because "she wishe[d] to continue in restaurant and catering as her occupation." The Bankruptcy Court denied Reilly's dismissal motion simultaneously with Schwab's motion to sell Reilly's equipment.

Id. at 2671 n. 3 (citations omitted).

${ }^{211}$ See 11 U.S.C. $\$ 363($ b)(1), (f)(3) (2006) (stating trustee may, after notice and hearing, sell property of estate, and may do so free and clear of liens if, inter alia, surplus is generated for estate).

${ }^{212}$ See Schwab, 130 S. Ct. at 2668.

${ }^{213}$ Cf. In re Cottingham, No. 95-32441-B, 1996 WL 288393, at*1 (Bankr. W.D. Tenn. Apr. 25, 1996) ("The debtor orally amended his exemptions, but should now do so in writing."). 
Schedule C, in which case a new 30-day period extends from the time of the amendment. According to Rule 4003(b):

[T] he trustee or any creditors may file objections to the list of property claimed as exempt within 30 days after the conclusion of the meeting of creditors held pursuant to Rule 2003(a), or the filing of any amendment to the list or supplemental schedules unless, within such period, further time is granted by the court. ${ }^{214}$

Rule 4003(b) indicates that the debtor has the duty to amend the schedule to change the nature of her claimed exemption, and that the trustee has 30 days from the amendment to object. ${ }^{215}$ This the debtor in Schwab never did. ${ }^{216}$ Indeed, Schwab notified the debtor expressly that she had failed to exempt the thing-in-itself. ${ }^{217}$ Yet she did nothing to amend Schedule C. ${ }^{218}$

We have one last piece of business. We have emphasized the peculiar definition of value in section 522(a)(2) and how this provision inspired Judge Posner, avant la lettre, to adopt the position of the Schwab dissent. The Schwab majority never mentions section 522(a)(2). ${ }^{219}$ What does the Schwab majority imply about this provision?

According to the Schwab majority, valuation figures only in Column $4 .^{220}$ Column 4 is advisory to the trustee only. There is no role for valuation in the exemption process and, for that reason, no need for the trustee to challenge the debtor's valuation in the 30-day period. This saves the trustee from making routine objections to the debtor's valuation (whenever the number is less than the statutory limit). ${ }^{221}$ And, in any case, what would this hypothetical objection be? The trustee would simply be saying, "We think the value is higher. Give us more time to find a buyer to find out." Such an objection, if required, should always be granted. Why should a court value the claimed item when an auction is better suited to establish its actual realized value? But given this is always the nature of the objection, why

\footnotetext{
${ }^{214}$ FED. R. BANKR. P. 4003(b) (emphasis added).

${ }^{215}$ See id.

${ }^{216}$ See Schwab v. Reilly, 130 S. Ct. 2652, 2671 (2010) (Ginsburg, J., dissenting).

${ }^{217}$ See id. at $2671 \mathrm{n} .3$.

${ }^{218}$ See id. at 2671; Rosario-Farnula v. Wigberto (In re Barroso-Herrans), 524 F.3d 341, 345 (1st Cir. 2008) ("[ $[\mathrm{n}$ legal documents ambiguity is traditionally construed against the drafter, and that canon has special force in this context: after Taylor, a failure to object to a claimed exemption has very harsh consequences for the estate, and so it is most fair to place on the debtor the burden of claiming exemptions unambiguously." (citing Hyman v. Plotkin (In re Hyman), 967 F.2d 1316, 1319 n.6 (9th Cir. 1992))).

${ }^{219}$ See Schwab, 130 S. Ct. at 2652-69.

${ }^{220}$ See id. at 2661.

${ }^{221}$ See id. at 2661-62 (noting claimed exemption values need not reference estimated market value and trustee's objection duty only applies where claimed exemption exceeds statutory cap). As the majority emphasizes: "Where the debtor genuinely intended to claim nothing more than the face value of the exempt interest (which is rational if a debtor wishes to ensure that his aggregate exemptions remain within statutory limits), [the minority] approach would engender needless objections and litigation ...." Id. at $2668 \mathrm{n} .18$.
} 
require it at all? Let the trustee go out and find a buyer in order to liquidate the surplus! This will settle once and for all the value of the item. ${ }^{222}$

Given the majority view, section 522(a)(2) becomes a statute on how the debtor should advise the trustee as to the value of the exemption. Absurdly, the trustee does not usually care about historic value. He cares about the value at the time of a section 363(b) sale. Nevertheless, Column 4's precatory advice is to be governed by this historic challenge. In most cases, none of this makes a difference, especially when personal property is at stake. Personal property usually depreciates in value. So a report of the historic value will tend to be overly optimistic. The trustee can make some sense of this in deciding whether or not to invest time and effort in seeking a buyer. Real property is a different matter. In the halcyon early years of this decade, real estate prices often rose, even over the life of an ordinary chapter 7 liquidation. In these cases, historic value serves the trustee not at all.

On the other hand, it should be remembered that a debtor must file her Schedule $\mathrm{C}$ very soon after a voluntary bankruptcy petition. ${ }^{223}$ Given this timeline, the difference between historic valuation and present valuation is likely to be minimal. So, as a practical matter, it is not consequential that Column 4 be governed by valuation on the day of the bankruptcy petition.

Has the majority read section 522(a)(2) out of the Bankruptcy Code-that tobe-avoided interpretative faux pas? I think the Schwab majority can be acquitted of this $\sin$. True, its limitation to the governance of Column 4 reduces it in dignity and renders it slightly absurd, but nevertheless it still has an Osric-like role in the great drama of bankruptcy exemption procedure.

\section{CONCLUSION}

Although the opinions in $S c h w a b$ may seem a dense squabble over the meaning of bureaucratic forms, behind the majority opinion is complete re-theorization of the exemption process in bankruptcy. The majority finds that valuation plays no role in the exemption process. No magic transformation of a monetarily limited exemption into an in-kind exemption occurs just because the debtor recites a below-limit value to the property on her Schedule C. As valuation plays no role in the exemption process, the trustee need never object to the debtor's estimate of the market value of the thing to be exempted. In this vision, there is a fundamental difference between

\footnotetext{
${ }^{222}$ If this is always a winning objection, then the court actually never values the thing, even if the $S c h w a b$ minority's vision is true.

${ }^{223}$ The Rules are confusing on this point. According to Bankruptcy Rule $1007(\mathrm{c})$, documents required under Rule 1007(b)(1) must be filed within 15 days of the bankruptcy petition. FED. R. BANKR. P. 1007(c). Rule 1007(b)(1)(A) refers to "schedules of assets and liabilities," but does not refer expressly to Schedule C. FED. R. BANKR. P. 1007(b)(1)(A). But Rule 4003(a) indicates that, "[i]f the debtor fails to claim exemptions or file the schedule within the time specified in Rule 1007, a dependent of the debtor may file the list within 30 days thereafter." FED. R. BANKR. P. 4003(a). Rule 4003(a) therefore contemplates that the time limit of Rule 1007(c) is supposed to apply to Schedule C. See Ahart, supra note 72, at 247.
} 
in-kind exemptions and monetarily limited exemptions. In-kind exemptions are in fact rarely litigated. When they exist, the trustee's hypothetical judicial lien never attaches. But where the exemption is monetarily limited, the trustee's judicial lien attaches and remains in place until the property is sold or the trustee abandons his rights back to the debtor. 